\title{
Contamination and toxicity in a subtropical Estuarine Protected Area influenced by former mining activities
}

\author{
Fernando Cesar Perina ${ }^{1,2 *}$, Denis Moledo de Souza Abessa ${ }^{2}$ (이 \\ 1 Universidade de São Paulo, Programa de Pós-Graduação em Oceanografia. Instituto Oceanográfico da Universidade de São Paulo \\ (Praça do Oceanográfico - 191 - Butantã - 05508120 - São Paulo - SP - Brazil) \\ 2 Universidade Estadual Paulista, Campus do Litoral Paulista - UNESP-CLP - São Vicente \\ (Praça Infante Dom Henrique s/nº - Parque Bitaru - 11.330-900 - São Vicente - SP - Brazil) \\ *Corresponding author: perinafc@gmail.com
}

\section{Abstract}

The present paper reviews information about sources, fate, concentrations and toxicity of the metals found in the Cananéia-Iguape Estuarine Complex (CIEC), which is within a Ramsar site, the Cananéia-lguape-Peruíbe Environmental Protected Area (CIP-PA). The main sources of metals to CIEC are the former mining sites located upstream, on the Ribeira de Iguape River basin. $\mathrm{Pb}$ is reported as the element of primary concern, but $\mathrm{Cu}, \mathrm{Zn}, \mathrm{Cr}$ and $\mathrm{As}$ have been detected in sediments and biota. In general, higher levels of metals are associated with muddy sediments, in depositional portions of the estuary. Metals appear to be bioavailable, as sediment toxicity has been reported, together with bioaccumulation and sub-chronic effects in fish and invertebrates. Areas with higher concentrations of metals and more severe sediment toxicity are not necessarily the closest to the sources. The worse conditions occur in depositional sites, which depend on rainfall in catchment basin and hydrological processes in the estuary. In fact, during the flooding season the deposition of particles seems to move southward, carrying metals to the southern portion of the CIEC. The results suggest that the protection objectives are not being fully achieved, demanding actions to ensure control of both internal and external sources of contaminants for the CIEC. Additionally, new enforcements and actions are required to control the contamination sources of mining residues located upstream. The current review highlights that estuarine and marine protected areas may be impacted by contaminants released from distant sources, and this situation should be properly addressed in management plans.

Descriptors: Sediment, Metals, Pollution Sources, Bioaccumulation, Ecotoxicology.

\section{INTRODUCTION}

Estuaries are coastal transition zones between fresh-water and seawater that present substantial gradients of abiotic parameters and which are most highly affected by freshwater inflows and tidal regimes. Therefore, large variations in salinity, $\mathrm{pH}$, temperature and geochemical conditions may occur in

Submitted on: 01/March/2020

Approved on: 08/May/2020

Editor: Rubens M. Lopes

(C) 2020 The authors. This is an open access article distributed under the terms of the Creative Commons license. these transitional environments, even in relatively short spatial and temporal scales (Elliott and McLusky, 2002). The hydrodynamics of estuaries favor the retention of nutrients and consequently the primary production, thus placing these environments among the most biologically productive coastal ecosystems on the planet (Miranda et al., 2002; McLusky and Elliott, 2004).

Estuaries also exhibit geomorphological and physical-chemical characteristics that favor material deposition such as organic material and man-made contaminants (Du Laing et al., 2009). Estuarine areas normally present low energy from waves and 
currents making it difficult for the chemicals to disperse, frequently resulting in accumulation of organic and inorganic substances in the sediments. Once in the sediment, contaminants may directly affect the benthic biota, but they may also return to the water column through various physical, chemical and biological processes, thus resulting in even greater ecological effects (Chapman and Wang, 2001). These characteristics make estuaries very sensitive; and one of the most significantly affected ecosystems by human activity (Lewis et al., 2011).

Changes in salinity, temperature, $\mathrm{pH}$ and oxidation/reduction potential regulate the retention, and release of metals associated with the finest sediment fraction, organic material, iron oxides and sulfides (Caporale and Violante, 2016). The resuspension of contaminated sediments can occur naturally, as is observed in the turbidity maximum zone (TMZ). These zones mainly occur in estuaries in which salinity is partially stratified. The turbulent movement induced by currents close to the bottom causes sediment resuspension and increases the levels of suspended sediments; up to 100 times higher than those found upstream and downstream (Postma, 1967). Besides, the TMZ is displaced following the tidal cycles and the rainfall precipitation regime, being subject to daily and seasonal variations.

Metals in estuaries may come from natural sources involving both local geological composition and the leaching of soils and rocks present in the drainage basin. However, for the most of the toxic metals, the greatest contribution comes from human sources, such as domestic and industrial effluents, agricultural pesticides (Ebrahimpour and Mushrifah, 2008), atmospheric deposition (Pereira et al., 2006) and mining activities. It is important to note that, even when pollution sources are located at substantial distance away from estuaries, the contaminants may reach the estuarine ecosystems. Studies reported that mining activities located hundreds of kilometers upstream were responsible for the contamination of estuarine zones worldwide, largely due to the transport of residues and sediments containing absorbed metals (Johnson et al., 2005; Price et al., 2005; Masson et al., 2006; Osher et al., 2006).

Sediments are important indicators of environmental quality and can be considered one of the most complex matrices to exist in aquatic ecosystems
(Power and Chapman, 1992). Chemical analyses may provide information on specific levels of contaminants, which, if bioavailable, may lead to toxicity and bioaccumulation (USEPA, 2004). Nevertheless, different types of associations between sediments and contaminants may reduce their bioavailability (Simpson et al., 2016). Thus, chemical analyses indicate the nature of the contaminants present in the environment and quantify their concentrations; but they do not provide information on the possible effects on aquatic organisms. Therefore, a sediment quality assessment performed exclusively through chemical analyses is insufficient for estimating damages to biota. Hence, an ecotoxicological approach is required for evaluating sediment quality, since it provides information on the biological effects caused by contaminants (Chapman, 2016).

In order to evaluate the presence of metals in an important subtropical estuarine protected area, this paper reviews a series of studies on the contamination and toxicity of the sediments in Cananéia-Iguape Estuarine Complex (CIEC). The CIEC is located on the southern coast of Sao Paulo State, Brazil, and it is influenced by former mining activities along the Ribeira de Iguape River catchment basin. Thus, the current information on the extent of metal contamination in the Ribeira de Iguape River was also analyzed, since it is the most important freshwater and fine sediment contributor to the CIEC (Barcellos et al., 2009).

\section{METHODS}

This literature review considered studies on contamination carried out in the CIEC and in the Ribeira de Iguape River catchment basin (also known as the Ribeira Valley), which has a history of contamination by metals (Eysink et al., 1988; Guimarães and Sígolo, 2008a; Abessa et al., 2014). The criterion for inclusion of a paper into this review was that the study had to have analyzed field-collected samples to measure metal in sediments or biological effects of contaminants. To obtain articles that fit these criterion, we conducted sequential searches in the relevant databases (Scopus, Web of Knowledge and SciElo) by crossing the terms *contamin-*, or *pollut-*, or *toxic-*, or *bioacum-*, or biomarker against the terms "Cananeia Iguape Peruibe protected area", or "Cananeia", or "Ribeira de Iguape". We searched for additional studies by examining monitoring reports 
available on databases of environmental agencies as well as academic thesis and dissertations that are available on digital libraries. We recognize that some of the information about metal contamination in the CIEC is unpublished (academic documents not available on the web) or part of monitoring reports.

This review selected only papers that have adopted analytical procedures widely accepted around the world and quality control procedures (quality assurance/quality control - QA/QC). Besides, this review did not aim to discuss differences among analytical methods employed in each of the selected papers, focusing on spatial and temporal variations of contamination. We also did not aim to discuss the experimental design adopted in each of the selected papers, such as field sampling techniques and the use of replicates; instead, we focused on the reported results, including contamination and biological data (bioaccumulation, toxicity, genotoxicity, cytotoxicity, or biochemical biomarker) indicating potential adverse effects on aquatic biota.

The information obtained from the literature was used to respond to a series of questions: Is the CIEC contaminated by metals? If so, which elements are the main contaminants? How are contaminants distributed along the estuary? Which are the primary contamination sources? Are concentrations high enough to cause adverse effects on the biota? If so, which types of effects and at which concentrations? How large is bioaccumulation of the different metals? Are there any implications to the public health? Based on the literature found, we produced a diagnostic for the studied area, including physical, geographical and socio-environmental aspects, the presence of sources of metals and other contaminants, and other information relevant to the comprehension of the pollution status of the study area. The compiled information was also used to produce recommendations to managers, stakeholders and authorities.

\section{STUDY AREA}

A protected area (PA) is defined by the International Union for Conservation of Nature as " $A$ clearly defined geographical space, recognized, dedicated and managed, through legal or other effective means, to achieve the long-term conservation of nature with associated ecosystem services and cultural values" (Day et al., 2012). The coastal zone of Brazil presents an extensive network of PAs, which forms a large ecological corridor, encompassing terrestrial, marine and estuarine areas. The Cananéia-lguapePeruíbe Protected Area (CIP-PA) is inserted in this network; this PA was created in 1984 through Brazilian Law No. 90.347; it covers the cities of Cananéia, Iguape, Peruíbe, Itariri, Pedro de Toledo, and Miracatu (IBAMA/SMA-SP, 1996). This protected area is part of the "Atlantic Forest Biosphere Reserve", recognized as such by UNESCO as 1991 (Lino et al., 2011); in addition, the CIP-PA was recently included in the Ramsar's List of Wetlands of International Importance (RSIS, 2017). The Ramsar Convention is the intergovernmental treaty that provides the framework for the conservation and wise use of wetlands and their resources (Ramsar Convention Secretariat, 2016). The CIP-PA Ramsar site includes the Cananéia-lguape Estuarine Complex (Figure 1), which is part of a region known as Lagamar. Since 2000, the region has been part of the global list of UNESCO's World Heritage Sites (Abdulla et al., 2013), as it is part of the "Atlantic Forest South-East Reserves" World Heritage site.

The Cananéia-Iguape Estuarine Complex (CIEC) is located on the southern coast of Sao Paulo State. It is comprised of the cities of Iguape, Ilha Comprida, and Cananéia, and it also includes Cardoso Island. CIEC has about $100 \mathrm{~km}$ length and an approximate area of $200 \mathrm{~km}^{2}$; this complex is located on a sandy coastal plain and has an intricate set of estuarine and lagoon channels (Figure 1). It was formed through five phases of transgression and regression of the ocean over the last 120,000 years (Suguio and Martin, 1978). The current configuration was obtained close to 5,100 years ago, when the average sea level was 4 meters above current levels and began to regress, thus forming the current system of channels and barrier islands (Suguio et al., 1988).

\section{CLIMATE}

The climate in the Lagamar region is classified as a humid subtropical climate ( $\mathrm{Cfa}$ ). Its average annual temperature is $21.2{ }^{\circ} \mathrm{C}$, and the relative humidity in the air averages approximately $88 \%$. Between spring and summer, tropical air masses prevail, while in the winter there is a predominance of polar air masses (Schaeffer-Novelli et al., 1990). Average annual precipitation exceeds $2200 \mathrm{~mm}$, with the highest amounts occurring from January to March (average 


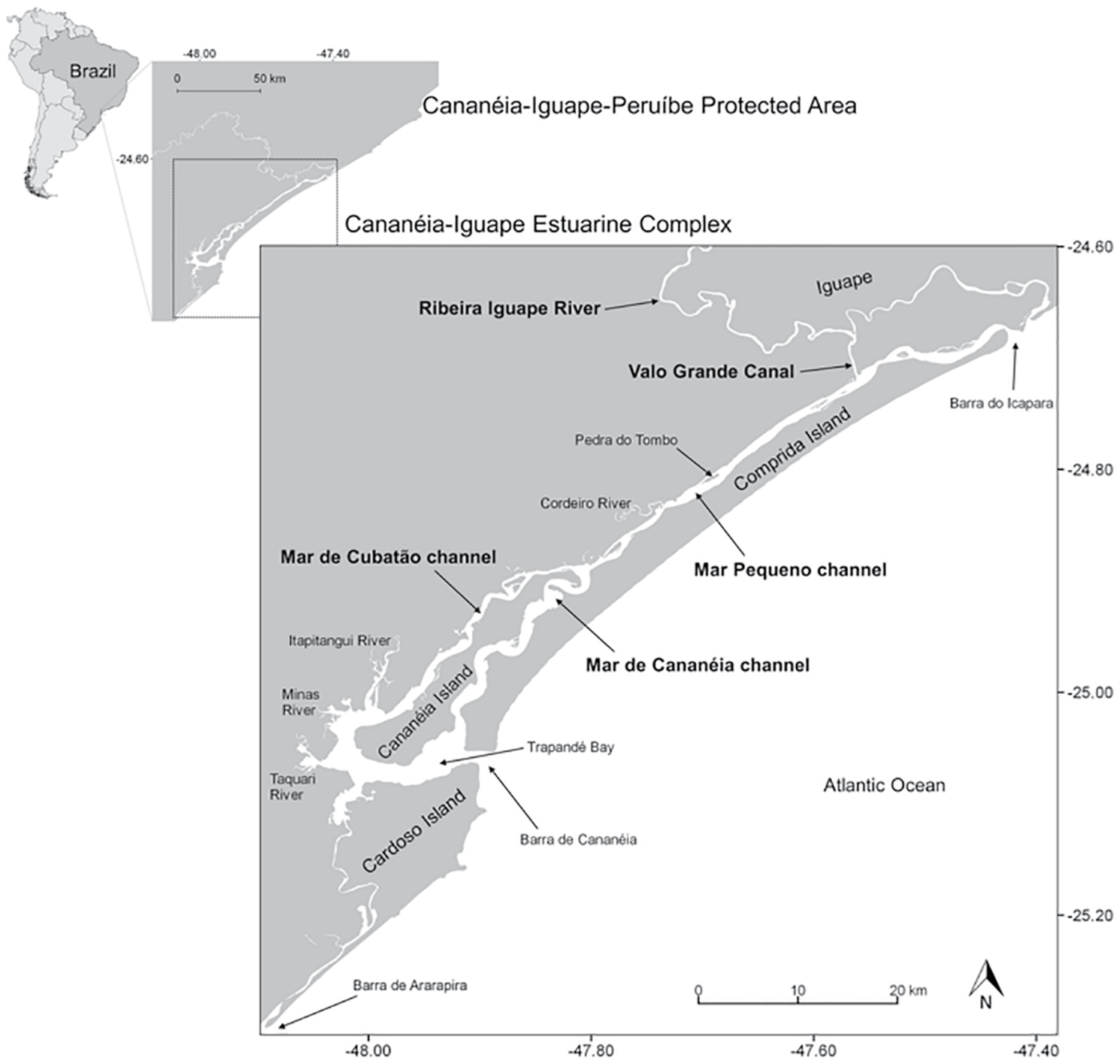

Figure 1. Cananéia-Iguape-Peruíbe Protected Area (CIP-PA) and overview of the Cananéia-lguape Estuarine Complex (CIEC).

monthly rainfall of $266.9 \mathrm{~mm}$ ) and the lowest amount recorded in July and August, when the average is 95.3mm (Mishima et al., 1986; Silva, 1989).

\section{HYDROGRAPHY AND HYDROLOGICAL DYNAMICS}

Tidal cycles associated with freshwater inflows and atmospheric precipitation cause wide amplitudes of salinity fluctuation throughout the CIEC. The Ribeira de Iguape River (RIR) is the main freshwater course in the complex and has the most significant influence on the salinity of the lagoon waters. CIEC also receives contributions from a vast network of smaller rivers, such as the Cordeiro River in the northern portion, the Taquari River, the Minas River, and the Itapitangui River in the southern portion (Figure 1). The flow rate of the RIR responds synchronously to variations in rainfall; it is lowest in June, when it averages $218 \mathrm{~m}^{-3} \mathrm{~s}^{-1}$, and it triples during the rainy season, when it averages $634 \mathrm{~m}^{-3} \mathrm{~s}^{-1}$ (DAEE, 2019). After the opening of an artificial canal known as the Valo Grande Canal (detailed below), the RIR inflow came to be almost completely directed to the CIEC through this canal.

The estuary connects to the ocean through three natural mouths known as Barra do Icapara, Barra 
de Cananéia and Barra do Ararapira (Figure 1). The longitudinal density gradient of the water and this freshwater inflow are the driving forces behind the stationary circulation in the CIEC; they are predominantly determined by tides (Miyao and Harari, 1989) and, to a lesser extent, by winds (Miranda et al., 1995). The tides in the estuary are semi-diurnal, with diurnal variations and maximum amplitudes of $1.25 \mathrm{~m}$ (Bernardes and Miranda, 2001).

The average annual salinity gradient along the CIEC has a spatial structure on its shallow and the deeper portions $(>2 \mathrm{~m}$ ). This gradient begins at the mouth of the Valo Grande Canal and continues toward the Barra do Icapara and Barra de Cananéia, branching southward into two channels, separated by the Cananeia Island; these branches are known as the Mar de Cubatão and the Mar de Cananéia. In the southern portion of the CIEC, Trapandé Bay connects the Mar de Cananéia channel to the Atlantic Ocean between Comprida Island and Cardoso Island (Figure 1). The average flood tide and ebb tide current speeds reach $2 \mathrm{~m} \mathrm{~s}^{-1}$ and $1 \mathrm{~m} \mathrm{~s}^{-1}$, respectively. Despite evidence indicating the relative seasonal persistence of saltwater within the estuary and in Trapandé Bay (Miyao et al., 1986) short-term episodes of intense continental runoff may move the saltwater wedge towards south (Mahiques et al., 2009; Conti et al., 2012).

The CIEC channels are known as the Mar Pequeno, the Mar de Cubatão and the Mar de Cananéia. The Mar Pequeno channel is bordered by the Barra do Icapara (northern estuary mouth) and by the confluence of the three channels in the middle of the estuary. The opening of the Valo Grande Canal is found within this channel. The tidal waves generally meet in the region known as Pedra do Tombo, which represents the central region of this water body (Miyao and Harari, 1989). The water column between the confluence of the three channels and the Valo Grande Canal is more homogenous than the southern portion (Fontes et al., 2019). Between the Valo Grande Canal and the Barra do Icapara, an abrupt increase in the saline gradient and current speeds are often observed due to the area's proximity to the ocean (Barrera-Alba et al., 2007).

The Mar de Cubatão channel extends from the northern area of Trapandé Bay to the confluence of the three channels in the middle section of the estuary. The average depth is $5 \mathrm{~m}$, with a maximum depth of $10 \mathrm{~m}$ at the connection with Trapandé Bay (Tessler and Furtado, 1983; Tessler and Souza, 1998). It is characterized as a polyhaline channel with an average salinity of approximately 21.3. The freshwater inflows from the Taquari, Madrina, Minas and Itapitangui Rivers create clear water column stratification, in which salinities gradually increase in the direction of the Mar Pequeno channel. Tidal current speeds vary from 0.7 to $1.0 \mathrm{~m}^{2} \mathrm{~s}^{-1}$ (Miyao and Harari, 1989).

The Mar de Cananéia channel is bordered by the Mar Pequeno channel and by the southern portion of Trapandé Bay; its depth averages $6 \mathrm{~m}$. In this body of water, a gradual increase in depth has been identified from the Mar Pequeno channel to Trapandé Bay; it reaches $15 \mathrm{~m}$ at some points (Tessler and Souza, 1998; Bernardes and Miranda, 2001). According to Miyao et al. (1986) the vertical salinity structure of the Mar de Cananéia channel underwent changes after the opening of the Valo Grande Canal. It came to be classified as partially mixed and weakly stratified estuary. Average salinity is approximately 22.5 , which classifies this channel as a polyhaline water body. Imbalanced tidal wave behavior provokes induction currents in opposite directions between the Mar de Cananéia and the Mar de Cubatão channels (Miyao et al., 1986). This characteristic has important implications for the distribution and deposition of fine sediments, organic matter and contaminants since the MTZ shifts with the tidal excursion.

\section{BIOLOGICAL PRODUCTIVITY}

The arrangement of the bays and the mouths of the rivers within the CIEC allows the retention of large amounts of nutrients, which enables high primary productivity (Tundisi and Matsumura-Tundisi, 2001), with implications on the estuarine and marine food chains. The input of nutrients (dissolved and particulate organic material, as well as inorganic compounds) largely comes from mangrove swamps (Schaeffer-Novelli et al., 1990). Phytoplankton production is an important source of particulate carbon, especially during peaks in primary production during the rainy summer season (Tundisi and MatsumuraTundisi, 2001). Furthermore, rates of secondary production of zooplankton exhibit clear seasonal variations that are largely influenced by the interaction between coastal waters and the elevated concentration of nutrients and organic material in estuarine 
waters (Ara, 2004). For this reason, the CIEC is home to extensive biological diversity and is an important estuary in terms of its primary productivity and it role as a nursery for South Atlantic fish species (Kelleher et al., 1995; Costa Neto et al., 1997). The estuarine channels are surrounded by abundant mangrove vegetation and serve as a nursery for economically important marine species (Mendonça and Katsuragawa, 2001; Mendonça and Miranda, 2008).

\section{SOCIO-ENVIRONMENTAL CONSIDER- ATIONS}

Apart from the ecological relevance, one of the objectives of the CIP-PA is to protect cultural and historical value for traditional people. The traditional people living in the region include Brazilian indigenous, Maroons (known as Quilombolas), and fisher-farmers (known as Caiçaras). The culture of the Caiçaras is influenced by the miscegenation of Amerindians, European colonists, and African Brazilians, and their production system is based mainly on local indigenous knowledge (Hanazaki et al., 2007). The main economic activities among traditional people are subsistence agriculture, artisanal fishing, tourismrelated activities and extraction of non-timber forest resources directed to commerce (Peroni et al., 2008). According to Hanazaki et al. (2007), the level of importance of each of those activities varies across communities in the same region.

One of the most important fishery resources on the estuary of Cananéia is the mangrove oyster (Crassostrea spp.). The principal technique of oyster exploitation is the "oyster fattening", which is an intermediary method among extractivism and full culture (Henriques et al., 2010). This technique consists of setting adult oysters in the intertidal zone until they reach the appropriate size for commercialization (Pereira et al., 2001). This management method is environmentally essential since the animals spawn in the fattening farms, allowing the natural replenishment of stocks (Galvão et al., 2000; Pereira et al., 2001). The fattening culture at CIEC is economically viable compared to full culture, as it aggregates market value to the oysters (Henriques et al., 2010). According to Barbieri et al. (2014), oyster fattening culture in the CIEC displays low potential environmental impact and considerably more positive than negative impacts on the social-economic of Cananéia.
In general, the economy of the region is based mainly on fishing, tourism and oysters cultivation (Mendonça and Katsuragawa, 2001; Barbieri et al., 2014; Machado et al., 2015); thus the local economy relies on the ecological services and goods, strongly depending on the ecological conservation. Therefore, in addition to its unquestionable ecological function, the CIEC has socioeconomic importance (Machado et al., 2010; Barcellini et al., 2013). Household incomes and education levels are both relatively low in the region, as are the municipal GDPs of the three cities located within the CIEC (Cananéia, Iguape, and Ilha Comprida).

The demographic density of the cities located within the CIEC is low relative to the rest of the Sao Paulo coast (Morais and Abessa, 2014). However, due to its tourist attractions, the cities within the CIEC experience seasonal variation in their populations for two- to three-month periods during the year, though there is no official data on this fluctuation for the whole CIEC. Becegato and Suguio (2007) reported the number of tourists reached 150,000 people only in the city of Ilha Comprida, against 10,000 of inhabitants. Thus, in this region there is a considerable increase in population size and, therefore, there is also an increase in waste production and the input of urban effluents into the surrounding bodies of water. It is important to note that, in 2009, solid waste from the cities still lacked an adequate destination (CETESB, 2010a). Local sanitation and public health systems are also inadequate, and a substantial number of households are not included in the regional sewer system (Morais and Abessa, 2014). In addition, this region is currently the furthest away from the implementation of a Coastal Management Plan in the state of Sao Paulo, and more studies are needed on this topic (Morais and Abessa, 2014).

\section{CHARACTERIZATION OF STRESSORS}

\section{THE OPENING OF THE VALO GRANDE CANAL}

The natural mouth of the Ribeira de Iguape River (RIR) is located within the CIP-PA, north of CIEC. The river is $470 \mathrm{~km}$ in length from its headwaters in the state of Paraná (within the Paranapiacaba Mountain Range) to the mouth in the Atlantic Ocean in the state of Sao Paulo (in the city of Iguape). With an area 
of approximately $25,000 \mathrm{~km}^{2}$, the drainage basin of the RIR is almost completely distributed between the Atlantic Plateau and the coastal province. This region is characterized by slopes and embedded wetlands and also includes coastal plains, as well as marine and fluvial terraces (SIG-RB, 2012).

The RIR is the main contributor of suspended sediments, nutrients and contaminants into the CIEC (Barcellos et al., 2009). According to Mahiques et al. (2013), the CIEC has undergone significant environmental changes over the last 150 years due to the construction of a $4 \mathrm{~km}$ artificial canal connecting the Ribeira de Iguape River to the inner portion of the estuary. The project, which was concluded in 1852, sought to diminish the costs of agricultural production and transportation to the main economic port located in the city of Iguape. Originally, the canal was $4.4 \mathrm{~m}$ in width and $2 \mathrm{~m}$ in depth, but after more than 150 years the width reached approximately $300 \mathrm{~m}$, and in some locations, depth can reach $7 \mathrm{~m}$.

The Valo Grande Canal was closed in 1978 in order to minimize financial losses to agriculture in areas located upstream. However, during the El Niño oscillation of 1983, the rock and sand barrier was destroyed by significant floods. The coastal plain where the canal was dug underwent erosion, leading to the silting of the port areas of Iguape and the deposition of sediments in adjacent lagoon areas. In addition, approximately $70 \%$ of the main flow of the RIR was transferred to the CIEC, a process that decreased the system's salinity (Mahiques et al., 2013). In the city of Cananéia, for example, which is located $60 \mathrm{~km}$ to the south of the mouth of the canal, salinity can be found to be zero during the summer (Mahiques et al., 2009).

There is evidence that changes in salinity have affected the local biota since the opening of the Valo Grande Canal, with reports on the effects on ichthyofauna (Barcellini et al., 2013), phytoplankton (Kutner and Aidar-Aragao, 1986), foraminifera (Mahiques et al., 2009), and halophytes (Schaeffer-Novelli et al., 1990; Cunha-Lignon et al., 2011). According to Martinez et al. (2013), an abrupt change in the overall composition of molluscan fauna in the CIEC occurred after this canal was opened, as a consequence of the input of fresh water and contaminants.

The impact of the input of fresh water from the RIR is greater in the Mar Pequeno channel, which exhibits greater persistence under atypical conditions of low salinity and more physical habitat destruction; mangrove swamps have been replaced by freshwater macrophytes, and there has been an overall reduction in depth due to intense silting (Cunha-Lignon et al., 2009; Cunha-Lignon et al., 2011; Mahiques et al., 2013). According to Saito et al. (2001a), the rate of sediment deposition in this area is approximately $0.5 \mathrm{~cm}$ year $^{-1}$. Therefore, the Valo Grande Canal has clearly affected sedimentation patterns and the physical-chemical characteristics of the estuary, with increased transportation of silt and clay from the RIR into the southern portion of the CIEC (Barcellos et al., 2009). More drastically, the canal began to direct metals from mining areas of the Ribeira de Iguape River Valley to the inner portion of the CIEC (Mahiques et al., 2013), as described below.

\section{THE RIBEIRA DE IGUAPE RIVER VALLEY AND ITS HISTORY OF METAL CONTAMINATION}

Approximately $39 \%$ of the Ribeira de Iguape River catchment basin is located in the northeastern region of Paraná State while $61 \%$ of which is located in southeastern Sao Paulo state, where it occupies approximately $17,000 \mathrm{~km}^{2}$ (Theodorovicz and Theodorovicz, 2007). The Ribeira Valley is home to most of the remaining continuous Atlantic Forest in the country - out of the $7 \%$ of this biome that remains in Brazil, $21 \%$ is located in this valley. For this reason, UNESCO declared the region to be a National Heritage Site in 1999, and approximately $50 \%$ of the Ribeira Valley became an Environmental Protection Area (Santos and Tatto, 2008).

The Ribeira Valley region is currently slightly developed from a socioeconomic point of view; it has the lowest human development index in the state of Sao Paulo. However, due to its peculiar geology, the Ribeira River Valley has been one of Brazil's most important regions for mineral resources (Morgental et al., 1975). Mining along the upper course of the river (known as the Upper Ribeira Valley) began in the eighteenth century with manual gold and silver mining. In 1945, lead mining began on an industrial scale, followed by zinc mining (Lopes Junior, 2007).

Mining activities are recognized for their high impact on the environment, which results from the generation of toxic waste and acid or alkaline drainage that all come from the extraction and beneficiation of metals (Benedicto et al., 2008; Besser et al., 2009; Li et 
al., 2014). In addition, the inadequate disposal of this waste into the environment may have contaminated soils, groundwater, atmosphere, and surface waters (Corsi and Landim, 2003; Riba et al., 2005; Melo et al., 2012). According to Guimarães and Sígolo (2008a), mining residues are the main source of contamination in the RIR. They are present in the form of waste from the mining process (ore) and also as metallurgical waste (slag).

Lead mining in the Ribeira Valley was halted in 1995 as a result of an exhaustion of reserves, technical difficulties, and economic and environmental factors. However, wastes from the two main mines operating in the region, which were known as Rocha and Panelas, still remain along the banks of the Ribeira River and its tributaries (Figure 2). Waste from the Rocha mine was deposited close to the Rocha River and with a volume of approximately $3,000 \mathrm{~m}^{3}$. The volume of waste from the Panelas mine (Plumbum Mining Company) is approximately $89,000 \mathrm{~m}^{3}$ (Franchi, 2004), and the waste may still be found close to the bank of the RIR. It may be lixiviated or even eroded and transferred into the river (Abessa et al., 2014).

It is important to highlight that the concentrated waste from metallurgical activities performed by the Plumbum Mining Company was dumped into the RIR for more than forty years. Toxic waste dumping directly into the river was interrupted in 1991, and the material began to be deposited with mining waste on the banks of the RIR, with a total of at least $200,000 \mathrm{~m}^{3}$ of waste (Franchi, 2004) containing aluminum (Al), arsenic (As), barium (Ba), calcium (Ca), cadmium (Cd), chromium ( $\mathrm{Cr})$, copper $(\mathrm{Cu})$, iron $(\mathrm{Fe})$, potassium $(\mathrm{K})$, nickel $(\mathrm{Ni})$, manganese $(\mathrm{Mn})$, magnesium $(\mathrm{Mg})$, sodium $(\mathrm{Na})$, lead $(\mathrm{Pb})$, silicon $(\mathrm{Si})$ and zinc (Zn) (Guimarães and Sígolo, 2008a). These materials were deposited into the soil without any prior treatment and apparently without any concerns over contamination, since significant concentrations of metals were found in the RIR after 1995.

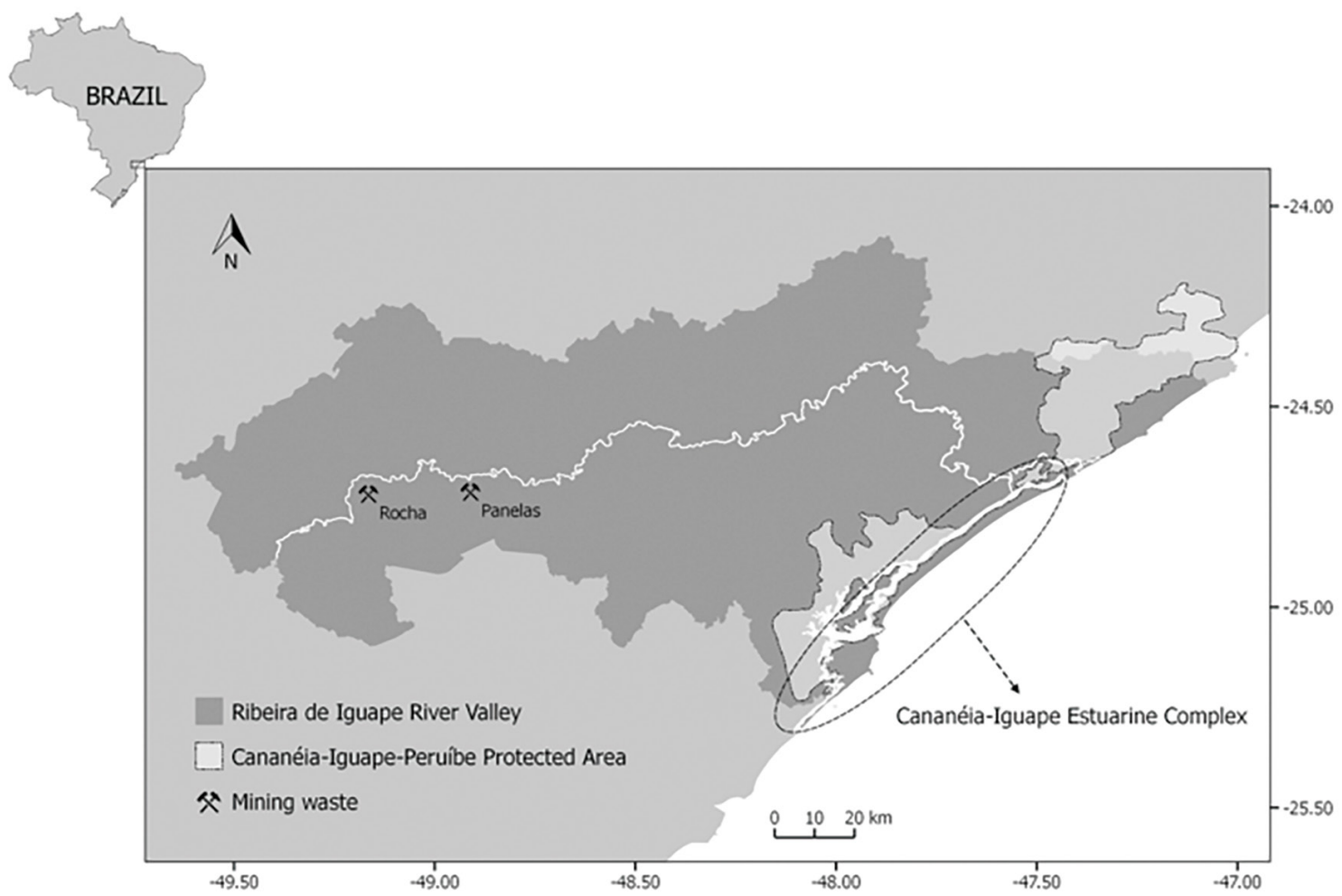

Figure 2. The Ribeira de Iguape River Valley showing the location in which mining wastes were deposited. 
Studies conducted during the period in which beneficiation and mining activities were performed reported high levels of $\mathrm{Pb}$ in the sediments of the RIR and its tributaries. Eysink et al. (1988) reported that the Rocha River reached $\mathrm{Pb}$ levels of $2,750 \mu \mathrm{g} \mathrm{L}^{-1}$ in the water and $1,440 \mathrm{mg} \mathrm{kg}^{-1}$ in the sediment. In the $\mathrm{RIR}$, the authors found high levels of $\mathrm{Pb}$ in the sediment $-4,000 \mathrm{mg} \mathrm{kg}^{-1}$. Lead levels above $500 \mathrm{mg} \mathrm{kg}^{-1}$ were also found at seven of the twelve sampling stations evaluated along the river in this study. The same authors reported high levels of $\mathrm{Pb}, \mathrm{Zn}$ and $\mathrm{Cu}$ in the sediments along the Ribeira de lguape riverbed, with a predominance close to the mining areas. At that time, the sediments that were collected close to the mines presented metal values at concentrations of $10^{2}-10^{3} \mathrm{mg} \mathrm{kg}^{-1}$, while this concentration varied from $10 \mathrm{mg} \mathrm{kg}^{-1}$ to $10^{2} \mathrm{mg} \mathrm{kg}^{-1}$ close to the estuary (Eysink et al., 1987; Eysink et al., 1988). In a further study, Eysink et al. (1991) reported $\mathrm{Pb}$ concentrations in sediments from the RIR between $105 \mathrm{mg} \mathrm{kg}^{-1}$ and $358 \mathrm{mg} \mathrm{kg}^{-1}$.

The Environmental Company of Sao Paulo State (CETESB) published an assessment of the quality of the Ribeira de Iguape River and its tributaries based on data obtained in 1998. The document reported $\mathrm{Pb}$ concentrations between $41.7 \mathrm{mg} \mathrm{kg}^{-1}$ and $389 \mathrm{mg} \mathrm{kg}^{-1}$ in the sediments (CETESB, 2000). In 2002, the CETESB began to include sediment quality assessments in its "Sao Paulo State Surface Water Monitoring Program". Because Brazil lacks standards for concentrations of contaminants in sediments, the CETESB uses quality criteria established by the Canadian Council of Ministers of the Environment, or the (CCME, 2002). This guide establishes two types of guideline values for toxic substance limits: one for threshold effect (Interim Sediment Quality Guidelines, or ISQG; also known as the threshold effect level or TEL), and the other for the probable effects level (PEL). According to the reports published by the CETESB, metal levels have been above ISQG/TEL every year, with the exception of 2002 and 2009 (CETESB, 2003; 2010b). In 2004 and 2006, values above the PEL were reported for $\mathrm{Pb}$ and $\mathrm{As}$, respectively. Due to the origin of the sediment matrix of the river basin, $\mathrm{Al}, \mathrm{Fe}$ and $\mathrm{Mn}$ have always been present in high concentrations in RIR sediment (CETESB, 2005; 2007). Only one site is monitored for ecotoxicity, and acute toxicity has thus far not been observed in the amphipod crustacean Hyalella azteca.
More recent studies have shown that the effects of lead metallurgy and mining are still present in the RIR and its tributaries (Corsi and Landim, 2002; Moraes et al., 2004; Cunha et al., 2005; Guimarães and Sígolo, 2008a). These studies have reported concentrations of metals in the sediments, particularly in the case of $\mathrm{Pb}$, which was found above regional background levels proposed by Morgental et al. (1978). According to these authors, the range of $\mathrm{Pb}$ levels before the effects of human activity was 12 to $16 \mathrm{mg} \mathrm{kg}^{-1}$.

Cunha et al. (2005) found $\mathrm{Pb}$ concentrations as high as $175.5 \mathrm{mg} \mathrm{kg}^{-1}$ in the RIR sediments and $527.2 \mathrm{mg} \mathrm{kg}^{-1}$ in one of its tributaries (the Betarí River, close to the city of Iporanga, Sao Paulo state). However, the authors observed a decrease in $\mathrm{Pb}$ concentrations in sediments from the RIR and its tributaries relative to the results of previous studies (Eysink et al., 1988; Eysink et al., 1991; CETESB, 2000). Lopes Junior et al. (2007) have also suggested a decrease in $\mathrm{Pb}$ concentrations over time in both the waters and the sediments of the RIR. In addition, the CETESB (2007) reported that the RIR is going through a natural recovery process induced by the control measures imposed by environmental agencies. Indeed, Abessa et al. (2012) reported an absence of acute toxicity to the cladoceran Daphnia similis, for both water and sediment samples collected from six sampling stations in the upper course of the RIR. Morais et al. (2013) evaluated the presence of $\mathrm{Al}, \mathrm{As}, \mathrm{Cd}, \mathrm{Cr}, \mathrm{Cu}, \mathrm{Fe}$, $\mathrm{Mn}, \mathrm{Ni}, \mathrm{Pb}$ and $\mathrm{Zn}$ in sediment samples and reported concentrations below the ISQG.

Though the literature indicates the occurrence of an environmental recovery process along time in the RIR, recent studies have reported the persistence of metals in abiotic compartments (Guimarães and Sígolo, 2008a; Melo et al., 2012) and in the biota (Guimarães and Sígolo, 2008b; Rodrigues et al., 2012). Therefore, we can conclude that the contamination has not yet been completely removed. This finding has been corroborated by studies on the release of metals by soils in the region (Buschle et al., 2010; Kummer et al., 2011).

The recovery process aids in returning the ecosystem to a state similar to that which was observed before the contamination occurred (Bradshaw, 1997; Garten and Ashwood, 2004). In the case of the RIR, this process includes the natural removal of contaminated waste and its dilution through the physical 
and chemical processes within the drainage basin. The waters of the RIR are slightly alkaline and present high levels of dissolved oxygen, resulting in a markedly oxidizing environment (Eh between $+320 \mathrm{mV}$ and $+440 \mathrm{mV}$ ), which favors the incorporation of metals into the suspended particles. Metals are thus easily remobilized for the water column and transported downstream (Corsi and Landim, 2002; Melo et al., 2012). Guimarães and Sígolo (2008b) highlighted that metals are migrating along the course of the RIR; they are incorporated into suspended material and made bioavailable for filter feeder mollusks, as was observed in the freshwater clam Corbicula fluminea.

Moraes et al. (2004) used $\mathrm{Pb}$ isotope tracers to identify sources of metals in the sediments of the lower course of the RIR and in the CIEC. The authors concluded that the found contamination came from the Upper Ribeira Valley mines. According to the study, the sediments carried along the river may include a mixture of various types and eroded soils in the Ribeira Valley, but the isotopic signatures of these materials coincide with those of ore and mining wastes discarded along the banks of the RIR. The study also suggests that the transportation of $\mathrm{Pb}$ and other associated metals has occurred through solid particles from ore, as well as through particles absorbed by minerals in the fine-grained sediment fraction.

\section{CLIMATE INFLUENCE ON SEDIMENTS AND CONTAMINANTS TRANSPORT TO THE CIEC}

As some authors have demonstrated, the metals released in the Upper Ribeira Valley are transported downstream (Corsi and Landim, 2002; Melo et al., 2012; Guimarães and Sígolo, 2008b) and reach the CIEC (Moraes et al., 2004). Thus, during extreme weather events, this transport can be intensified, since larger amounts of sediments are remobilized along the drainage basin and redistributed, mainly in the estuarine region (Jonasson and Nyberg, 1999; Coppus and Imeson, 2002). According to Costa et al. (2009) the rainstorms have major role in removing contaminated sediments along the RIR basin.

In addition to transporting contaminants, episodes of strong rainstorms may also cause significant changes to the landscape and geomorphology of the CIEC. The geomorphological impacts of extreme weather events are closely related to factors such as the erodibility of the material of origin, topography, vegetation and how the land is used (Bull et al., 2000; Belmonte and Beltrán, 2001). Then, the increase in flow and water volume along the drainage basins is a secondary factor that may increase sediment transport through the basin, since bottom particles can be resuspended as a physical consequence of the increase in energy (Morgan et al., 1998).

The flow rate of the RIR in its lower course varies from 300 to about $1,200 \mathrm{~m}^{3} \mathrm{~s}^{-1}$. The variation in flow is strongly influenced by rainfall, since the precipitation volumes are the main factor in regulating the hydrological balance of drainage basins, controlling the quantity of water that flows into the rivers through both surface runoff and underground drainage (Morgan et al., 1998; Zhang et al., 2004). The Ribeira Valley region experiences a relatively high rainfall in the summer, though it does not experience a defined dry season. Annual rainfall in the region vary from approximately 1,200 to $2,700 \mathrm{~mm}$ (SSE/SP, 2010). However, the flow rate of the RIR frequently exceeds $2,500 \mathrm{~m}^{3} \mathrm{~s}^{-1}$; an extreme rate of $4,250 \mathrm{~m}^{3} \mathrm{~s}^{-1}$ was recorded in its lower course in 1999 (SIG-RB, 2012).

Episodes of flooding in the RIR basin are not uncommon, since the climatic conditions in the region are highly conducive to the occurrence of highly intense and long-lasting frontal precipitation. Additionally, the morphological characteristics of the basin are also conducive to the occurrence of major floods. In its middle course and upper course, the RIR and its tributaries flow through enclosed valleys at an elevated slope. In the lower course, in addition to receiving contributions from other rivers, the RIR acts as a typical lowland river, cutting through low wetlands on a very limited slope. The overlap of these two factors constitutes the basic cause of large-scale flooding, both in terms of peak flow rate and volume (DAEE, 1998).

Some studies showed that runoff might carry a series of contaminants that are deposited in the soil or associated with sediment particles (Bay et al., 1996; Allert et al., 2009). These contaminants tend to be deposited in areas of low energy, such as floodplains and estuaries (Du Laing et al., 2009). In these locations, the physical and chemical characteristics may alter the dynamic of the metals and, as a result, their bioavailability (Carr et al., 2000). Increased rainfall precipitation rates may contribute to seasonal variation 
of metal concentrations in the biota. Lacerda et al. (1985) reported that higher concentrations of metals in macroalgae from the coast of Rio de Janeiro were associated to an increase of levels in seawater, which, in their turn, were associated to the terrestrial runoff that was augmented due to the increased rainfall volumes.

Extreme weather events are of special concern in regions where inadequate disposal of mining residues is made. A monitoring study of three decades of metal contamination in Sepetiba Bay (Brazil) indicated that during heavy rains, runoff waters enriched in $\mathrm{Zn}$ and $\mathrm{Cd}$ reached the bay after a massive spill of tailings material, causing a sudden increase on the concentrations of $\mathrm{Cd}$ and $\mathrm{Zn}$ in seaweeds and oysters (Lacerda and Molisani, 2006). We observed that the flooding in the RIR has the potential to make an even greater impact: the areas in which mining waste is located may be eroded, and contaminants may be transported in large quantities into the CIEC.

In a study conducted in the RIR, Abessa et al. (2014) compared metal concentrations in sediments collected along the RIR under different weather conditions. The collections were performed during a period of low indices of precipitation (less than $35 \mathrm{~mm}$ over 20 days), after an extreme weather event in which precipitation above $220 \mathrm{~m}$ in 24 hours was recorded, and after moderate rainfall (approximately $65 \mathrm{~mm}$ in 7 days). Metal concentrations were highest in the fine sediments collected after the episode of intense rainfall and at a distance of approximately $150 \mathrm{~km}$ from the areas where the mining activity waste had been deposited. The results revealed much lower metal concentrations in the sediments collected during the dry period, as the concentrations were below the ISQG and the background values for the Ribeira Valley region (Morgental et al., 1978). After the period of moderate rains, $\mathrm{Pb}$ and $\mathrm{Cr}$ concentrations were found to be above the ISQG. Meanwhile, in the samples collected after the 2011 floods, $\mathrm{Cr}$ concentrations also exceeded the ISQG and $\mathrm{Pb}$ concentrations were above the PEL. It is worth nothing that, in the extreme rainfall event, the river rose 14 meters in 24 hours and the flood was the second largest in the region's history (SIG-RB, 2012).

These data suggest that high rainfall precipitations may contribute to an enrichment of metals in the CIEC. Then, we can infer that this enrichment occurs largely through the transportation and deposition of fine-grained sediments, which potentially carry higher quantities of metals.

\section{EXPOSURE CHARACTERIZATION TOTHE STRESSORS}

\section{METALS IN THE CIEC SEDIMENTS}

The evidence obtained in this analysis revealed that the northern and southern portions of the estuary complex are subject to different consequences of human activity, as well as to other types of pressures. In the northern region, the effects are predominantly caused by former mining activities in the Upper Ribeira Valley. Some others have suggested that the presence of an abandoned gold mine close to the northern portion of the estuary and a fertilizer factory located in the city of Iguape are also important sources of metals in this region (Azevedo et al., 2012a). The southern portion is highly influenced by the urban area of Cananéia City (Cruz et al., 2014; 2019; Gusso-Choueri et al., 2016). The sources of metal vary; they include marine sources (particularly antifouling paints), gas stations, domestic sewage and urban drainage. The input of contaminants may have a seasonal influence, since the region experiences high levels of tourism and the population size undergoes changes during the year (Morais and Abessa, 2014). However, the southern portion may also be subject to the influence of mining activities, a possibility that will be discussed below.

In recent decades, many studies have reported the presence of metals in sediments from the CIEC (Table 1). The first metal concentration assessments using sediments from the CIEC was performed in the 1980s, when the Ribeira Valley mining activities were being performed. In the mid-1980s, Pb concentrations as high as $160 \mathrm{mg} \mathrm{kg}^{-1}$ were found in sediments from areas within the estuary (Piva-Bertoletti and Padua, 1986). Eysink et al. (1988) reported the presence of $\mathrm{Pb}$ at $82 \mathrm{mg} \mathrm{kg}^{-1}$ in sediment samples from the estuary close to the natural mouth of the RIR. In the southern portion, Tessler et al. (1987) found Pb concentrations varying from 0.30 to $247 \mathrm{mg} \mathrm{kg}^{-1}$, as well as $\mathrm{Zn}$ at 1.4 to $105 \mathrm{mg} \mathrm{kg}^{-1}$ and $\mathrm{Cu}$ at 0.05 to $292 \mathrm{mg}$ $\mathrm{kg}^{-1}$. According to these authors, elevated metal concentrations may have caused by the transport of fine sediments through the RIR and into the estuary. 
Table 1. Maximum concentrations (in $\mathrm{mg} \mathrm{kg}^{-1}$ ) of metals and arsenic reported in sediments in the Cananéia-lguape Estuarine Complex and their respective ISQG and PEL values.

\begin{tabular}{|c|c|c|c|c|c|c|c|c|c|c|}
\hline Location & As & Cd & $\mathrm{Cr}$ & $\mathrm{Cu}$ & Hg & $\mathbf{P b}$ & Zn & $\begin{array}{l}\text { Anal. } \\
\text { proc. }\end{array}$ & Digestion method & Reference \\
\hline \multirow{2}{*}{$\begin{array}{l}\text { Close to the } \\
\text { natural mouth } \\
\text { of the RIR }\end{array}$} & & $<0.19$ & & 13.1 & 0.15 & 82.0 & 58.9 & NR & APHA (1980) & Eysink et al. (1988) \\
\hline & & 0.13 & 7.8 & 9.83 & & 29.04 & 31.16 & ICPOES & $\begin{array}{l}\text { EPA 821/R-91/100 } \\
\text { (Allen et al., 1993) }\end{array}$ & $\begin{array}{c}\text { Campos et al. } \\
\qquad(2016)\end{array}$ \\
\hline \multirow{10}{*}{$\begin{array}{l}\text { Mar Pequeno } \\
\text { channel }\end{array}$} & & & & & & 160.0 & & NR & NR & $\begin{array}{c}\text { Piva-Bertoletti } \\
\text { and Padua (1986) }\end{array}$ \\
\hline & & & & 292 & & 247 & 105 & NR & NR & $\begin{array}{l}\text { Tessler et al. } \\
\text { (1987) }\end{array}$ \\
\hline & & & & $46^{b}$ & & $197^{b}$ & $135^{b}$ & ICPOES & $\begin{array}{l}\text { Method 3050B } \\
\text { (USEPA, 1996) }\end{array}$ & $\begin{array}{l}\text { Mahiques et al. } \\
\text { (2013) }\end{array}$ \\
\hline & 3.49 & $<0.1$ & 29.4 & 11.5 & & 30.7 & 49.4 & NR & $\begin{array}{l}\text { Method 3051A } \\
\text { (USEPA, 2007a) }\end{array}$ & CETESB (2014) \\
\hline & & 0.28 & 11.21 & 16.07 & & 51.63 & 37.01 & ICPOES & $\begin{array}{l}\text { EPA 821/R-91/100 } \\
\text { (Allen et al., 1993) }\end{array}$ & Cruz (2014) \\
\hline & & 0.07 & 20.38 & 5.47 & 0.06 & 13.08 & 23.32 & ICPOES & $\begin{array}{l}\text { EPA 821/R-91/100 } \\
\text { (Allen et al., 1993) }\end{array}$ & Araújo (2014) \\
\hline & & 0.17 & 8.59 & 7.99 & & 32.84 & 32.62 & FAAS & $\begin{array}{l}\text { EPA 821/R-91/100 } \\
\text { (Allen et al., 1993) }\end{array}$ & $\begin{array}{c}\text { Gusso-Choueri et } \\
\text { al. (2015) }\end{array}$ \\
\hline & 11 & $<0.6$ & 70.1 & 16.73 & & 72.7 & 176 & NR & $\begin{array}{l}\text { Method 3051A } \\
\text { (USEPA, 2007a) }\end{array}$ & CETESB (2015) \\
\hline & & 0.16 & 9.13 & 10.95 & & 33.41 & 33.57 & ICPOES & $\begin{array}{l}\text { EPA 821/R-91/100 } \\
\text { (Allen et al., 1993) }\end{array}$ & $\begin{array}{c}\text { Campos et al. } \\
\text { (2016) }\end{array}$ \\
\hline & & & & 18.74 & & 177.5 & 123.0 & ICPOES & Pueyo et al. (2001) & $\begin{array}{l}\text { Tramonte et al. } \\
\qquad(2018)\end{array}$ \\
\hline \multirow{9}{*}{$\begin{array}{l}\text { Mar de } \\
\text { Cananéia } \\
\text { channel }\end{array}$} & & & $52.2^{b}$ & $32.1^{b}$ & & $68.2^{b}$ & $92.1^{\mathrm{a}}$ & ICPOES & $\begin{array}{l}\text { Method 3050B } \\
\text { (USEPA, 1996) }\end{array}$ & $\begin{array}{l}\text { Mahiques et al. } \\
\qquad(2009)\end{array}$ \\
\hline & 12.1 & & 76 & & & & 96 & INAA & - & $\begin{array}{l}\text { Amorim et al. } \\
\qquad(2008)\end{array}$ \\
\hline & & 5.3 & 280 & 35 & & 56 & 74 & GFAAS & $\begin{array}{l}\text { Method } 7010 \\
\text { (USEPA, 2007b) }\end{array}$ & $\begin{array}{l}\text { Aguiar et al. } \\
\qquad(2008)\end{array}$ \\
\hline & & & & & $<0.10$ & & & ICPAES & Horvat (1996) & $\begin{array}{l}\text { Azevedo et al. } \\
\text { (2011) }\end{array}$ \\
\hline & 10 & $<0.1$ & 38.8 & 12.9 & & 25.7 & 57.2 & NR & $\begin{array}{l}\text { Method 3051A } \\
\text { (USEPA, 2007a) }\end{array}$ & CETESB (2014) \\
\hline & & 0.76 & & 61.7 & & & 71.6 & FAAS & $\begin{array}{l}\text { Method 3050B } \\
\text { (USEPA, 1996) }\end{array}$ & Cruz et al. (2014) \\
\hline & & 0.14 & 31.97 & 16.27 & 0.12 & 40.24 & 45.18 & ICPOES & $\begin{array}{l}\text { EPA 821/R-91/100 } \\
\text { (Allen et al., 1993) }\end{array}$ & Araújo (2014) \\
\hline & 6.23 & $<0.5$ & 25 & 13 & & 12.5 & 43 & NR & $\begin{array}{l}\text { Method 3051A } \\
\text { (USEPA, 2007) }\end{array}$ & CETESB (2015) \\
\hline & & 0.04 & 3.84 & 1.97 & & 8.68 & 3.84 & FAAS & $\begin{array}{l}\text { EPA 821/R-91/100 } \\
\text { (Allen et al., 1993) }\end{array}$ & $\begin{array}{c}\text { Gusso-Choueri et } \\
\text { al. (2015) }\end{array}$ \\
\hline \multirow{5}{*}{$\begin{array}{l}\text { Mar de } \\
\text { Cubatão } \\
\text { channel }\end{array}$} & & $<0.20$ & & 3.16 & $<0.05$ & $<3.95$ & 11.3 & NR & APHA (1980) & Eysink et al. (1988) \\
\hline & 9.4 & & 41 & & & & 32 & INAA & - & $\begin{array}{l}\text { Amorim et al. } \\
\qquad(2008)\end{array}$ \\
\hline & & 6.1 & 133 & 25 & & 55 & 56 & GFAAS & $\begin{array}{l}\text { Method } 7010 \\
\text { (USEPA, 2007) }\end{array}$ & $\begin{array}{l}\text { Aguiar et al. } \\
\qquad(2008)\end{array}$ \\
\hline & & & & & $<0.10$ & & & ICPAES & Horvat (1996) & $\begin{array}{l}\text { Azevedo et al. } \\
\qquad(2011)\end{array}$ \\
\hline & & $<0.14$ & & $<0.14$ & & $<0.14$ & $<0.14$ & FAAS & $\begin{array}{l}\text { Method } 200.8 \\
\text { (USEPA, 1999) }\end{array}$ & $\begin{array}{l}\text { Barros and Barbie- } \\
\qquad \text { ri (2012) }\end{array}$ \\
\hline
\end{tabular}


Continuation table 1.

\begin{tabular}{lcccccccccc}
\hline & $\mathbf{1 5 . 8}$ & & $\mathbf{6 0}$ & & & & 70 & INAA & $\begin{array}{c}\text { Method 3051A } \\
\text { (USEPA, 2007) }\end{array}$ & $\begin{array}{c}\text { Amorim et al. } \\
(2008) \\
\text { Trapandé Bay }\end{array}$ \\
& & $\mathbf{5 . 2}$ & $\mathbf{9 4}$ & 16 & & 24 & 56 & GFAS & $\begin{array}{c}\text { Method 7010 } \\
\text { (USEPA, 2007) }\end{array}$ & $\begin{array}{c}\text { Aguiar et al. } \\
(2008)\end{array}$ \\
\hline $\begin{array}{l}\text { Close to } \\
\text { Cardoso Island }\end{array}$ & & $<0.20$ & & 3.48 & 0.06 & $<3.87$ & 19.4 & NR & APHA (1980) & Eysink et al. (1988) \\
\hline $\begin{array}{l}\text { ISQG } \\
\text { PEL }\end{array}$ & 7.24 & 0.7 & 52.3 & 18.7 & 0.13 & 30.2 & 124 & & & CCME (2002) \\
\hline
\end{tabular}

Values marked in bold are above the ISQG; italics indicate violation of PEL; Letters a and b: Concentrations obtained from cores dated at the time of depositions that occurred (a) after the opening of the Valo Grande Canal and (b) after the mechanization of the local mining activity; $\mathrm{NR}=$ Not reported; Analytical procedures: ICPAES = Inductively Coupled Plasma Optic Emission Spectroscopy; FAAS = Flame atomic absorption spectrophotometry; ICPAES = Inductively Coupled Plasma Atomic Emission Spectroscopy; INAA = Instrumental neutron activation analysis; GFAAS = Graphite furnace atomic absorption spectrophotometer.

In a more recent study, Moraes et al. (2004) used $\mathrm{Pb}$ isotopes and corroborated the geochemical studies performed previously, which contributed the high concentrations of metals in the Mar Pequeno channel sediments (north portion of CIEC) to the mining activities performed in the Upper Ribeira Valley. Saito et al. (2001b) evaluated the geochronology of the CIEC sedimentation using dating with ${ }^{210} \mathrm{~Pb}$ and found that the RIR had a strong influence on sediment deposition. Other studies have reported that sedimentation rates are lower at north of Cananéia Island, since it does not receive direct freshwater inflows from the RIR. However, during the ebb tide, this location receives a high contribution of suspended sediments from the Mar Pequeno channel, which mainly come from the RIR by way of Valo Grande (Saito et al., 2001a). South of Cananéia Island, the sedimentation is more strongly influenced by tidal currents that may re-suspend fine sediments (Saito et al., 2001a).

Mahiques et al. (2013) analyzed the sediment profile in the north portion of the CIEC and found records of man-made metal input at a point located $20 \mathrm{~km}$ from the mouth of the Valo Grande Canal (in the direction of Cananéia Island). The study identified 150 years of metal input into the estuary resulting from human activity. According to the authors, the highest contamination levels occurred between 1940 and 1990, coinciding with the decades in which industrial-scale mining was performed in the Upper Ribeira Valley, approximately $300 \mathrm{~km}$ away from the Valo Grande Canal. Tramonte et al. (2018) performed the sequential chemical extraction of some metals on previously described sediment cores (Mahiques et al., 2013), and estimated the remobilization geochemical behavior. Concerning $\mathrm{Pb}$, the maximum available level (sum of all mobile fractions) was $177.55 \mathrm{mg} \mathrm{kg}$ 1. According to the study, $\mathrm{Pb}$ remains a concern in the system, since it presents strong association with $\mathrm{Fe}$ and $\mathrm{Mn}$ oxides, and can be remobilized in reducible conditions that dissolve those compounds. The authors highlighted the anthropic contribution of $\mathrm{Pb}$, being the mining activity in the Ribeira Valley considered the only potential source of $\mathrm{Pb}$ in the region.

High levels of $\mathrm{Pb}$ are still being identified in surface sediments of the CIEC. Cruz et al. (2019) found values above $51 \mathrm{mg} \mathrm{kg}^{-1}$ in the Mar Pequeno channel. This contamination is worrisome when it is compared to the guideline values proposed by the CCME (2002); ISQG is defined as $30.2 \mathrm{mg} \mathrm{kg}^{-1}$ for coastal sediments. These levels are similar to those found in areas with a high degree of degradation, such as the Santos - São Vicente Estuarine System (Abessa et al., 2008) and Aratu Bay, in the state of Bahia, northeastern Brazil (Onofre et al., 2007).

In the southern portion of the CIEC, the main source of contaminants is attributed to the city of Cananéia (Cruz et al., 2014; Gusso-Chueri et al., 2015). However, the levels of metals reported in this area may have a contribution of the mining sites located upstream the Ribeira de Iguape River (Cruz et al., 2019), because the distribution of these contaminants in superficial sediments around the Cananéia Island presents a seasonal variation. Amorim et al. (2008) found levels of $\mathrm{Cr}, \mathrm{Hg}, \mathrm{Zn}$, and As below the ISQG in sediments collected in the estuarine region. However, sediments from two stations (Mar de Cananéia channel and Trapandé Bay) presented high concentrations of $\mathrm{As}$ and $\mathrm{Cr}$ - amounts which exceeded ISQG values. 
In another study performed around Cananéia Island, Aguiar et al. (2008) found high concentrations of $\mathrm{Pb}\left(19-56 \mathrm{mg} \mathrm{kg}^{-1}\right), \mathrm{Cd}\left(4-6.1 \mathrm{mg} \mathrm{kg}^{-1}\right)$, and $\mathrm{Cr}$ (35$\left.280 \mathrm{mg} \mathrm{kg}^{-1}\right)$. The highest $\mathrm{Pb}$ levels corresponded to the sediments with the largest silt and clay fractions, which were collected north of Cananéia Island where the influence of continental drainage is more intense. The authors of the study found high levels of $\mathrm{Cd}$, with a maximum value of $6.1 \mathrm{mg} \mathrm{kg}^{-1}$ found in the Mar Cubatão channel. In addition, the $\mathrm{Cr}$ levels obtained were elevated and reached $280 \mathrm{mg} \mathrm{kg}^{-1}$ in the northern portion of the Mar de Cananéia channel.

Though Aguiar et al. (2008) found extremely high $C d$ levels in the Mar de Cananéia channel, the same result was not found in the Mar de Cubatão channel in a study performed by Barros and Barbieri (2012). The authors reported an absence of this metal in surface sediments, and $\mathrm{Pb}, \mathrm{Cu}$ and $\mathrm{Zn}$ concentrations were lower than those reported in the aforementioned studies (Table 1). These differences may be due to the analytical methodology used in each study, and particularly the effect of acid extraction used in the digestion of the sediment matrix. Nevertheless, the authors reported a predominance of $\mathrm{Pb}$ in $75 \%$ of the samples evaluated.

Fine sediment particles (e.g., clays and silts) and organic matter are known for having a higher electro-chemical affinity to metals, and thus for favoring the processes of sorption, complexation and co-precipitation between contaminants and the sediment (Moore et al., 1989). We analyzed the literature and concluded that both organic matter and muddy particles influence the spatial distribution of metals, especially in the southern portion of CIEC; published data show that the main zones of deposition (and consequently metals accumulation) are located in the Mar de Cananéia channel, following the seasonal shifts of the TMZ. This phenomenon may increase the sediment contamination southwards; in order that metals from the upper Ribeira de Iguape River basin reach the south portions of CIEC.

\section{METALS IN THE CIEC BIOTA}

Barros and Barbieri (2012) evaluated the concentrations of metals in oysters of the species Crassostrea brasiliana, which are collected and farmed for human consumption in the mangrove swamps in the CIEC. Lead concentrations in the soft tissues of the animals varied from 0.230 to $0.236 \mathrm{mg} \mathrm{kg}^{-1}$ in the wet weight basis (ww) and were higher than those found in the sediments. Zinc concentrations were the highest among metals studied, with average levels varying from 20.1 and $24.1 \mathrm{mg} \mathrm{kg}^{-1}$ (ww). However, these values are below the maximum limits established for bivalve mollusks by Brazilian law and recommended by both the Brazilian Health Surveillance Agency (ANVISA) and European Commission (EC). The maximum tolerant limit value is established at $1.5 \mathrm{mg} \mathrm{kg}^{-1}(\mathrm{ww})$ in the case of $\mathrm{Pb}$ (EC, 2006; ANVISA, 2013) and $50.0 \mathrm{mg} \mathrm{kg}^{-1}(\mathrm{ww})$ in the case of $\mathrm{Zn}$ (Brazil, 1965). Though the concentrations are below those considered to be risk values, these animals interact extensively with the sediments and tend to accumulate metals in their tissues (Rebelo et al., 2003). Furthermore, the animals in the aforementioned study were collected from the Mar de Cubatão channel, where metal concentrations are lower than those reported in the Mar de Cananéia channel sediment (Table 1). According to the historical report, oysters were once found throughout the CIEC and are now limited to the southern portion (Mendonça and Machado, 2010). This impact was caused by changes to the physical and chemical properties of the waters in the northern portion, which were themselves caused by the opening of the Valo Grande Canal.

In another study, metal concentrations were measured in C. brasiliana tissues, in individuals collected from the Mar de Cubatão channel, and the concentrations found (ww) were $0.02 \mathrm{mg} \mathrm{kg}^{-1}$ of $\mathrm{Hg}, 0.08 \mathrm{mg}$ $\mathrm{kg}^{-1}$ of $\mathrm{Pb}, 0.11 \mathrm{mg} \mathrm{kg}^{-1}$ of $\mathrm{Cd}, 2.6 \mathrm{mg} \mathrm{kg}^{-1}$ of $\mathrm{Cu}$ and $393 \mathrm{mg} \mathrm{kg}^{-1}$ of $\mathrm{Zn}$ (Machado et al., 2002). Only the $\mathrm{Zn}$ concentration was above the maximum limit of $50.0 \mathrm{mg} \mathrm{kg}^{-1}$ (ww) established by Brazilian law (Brazil, 1965). However, $\mathrm{Zn}$ is physiologically present at relatively high levels in the digestive glands and gills of bivalve mollusks (Viarengo et al., 1997).

Metal concentrations in oysters reported in other coastal areas of Brazil generally are presented in the dry weight basis of soft tissues. In order to perform a comprehensive comparison, we used a conversion factor of 6.8 for the dry weight to wet weight ratio for Crassostrea spp. (Wright et al., 1985). Thus, we observed that metal concentrations in oysters from CIEC are similar to those observed in animals from other estuaries under anthropogenic influence. SenezMello et al. (2020) found $0.11 \mathrm{mg} \mathrm{kg}^{-1}$ of $\mathrm{Cd}, 0.08 \mathrm{mg}$ 
$\mathrm{kg}^{-1}$ of $\mathrm{Cr}, 0.05 \mathrm{mg} \mathrm{kg}^{-1}$ of $\mathrm{Pb}$ and $294 \mathrm{mg} \mathrm{kg}^{-1}$ of $\mathrm{Zn}$ in the Potengi estuary (Northeast Brazil). However, concentration of $\mathrm{Zn}$ in oysters from $\mathrm{CIEC}$ was higher than in other coastal areas of the NE Brazil, such as $309 \mathrm{mg} \mathrm{kg}^{-1}$ in the Todos os Santos Bay (Amado-Filho et al., 2008) and $154 \mathrm{mg} \mathrm{kg}^{-1}$ in the estuary of Rio dos Cavalos, Rio Grande do Norte (Silva et al., 2003). On the other hand, $\mathrm{Zn}$ concentration reported in oysters from CIEC is about 30 times lower than that found in the Sepetiba Bay (SE Brazil), where the highest level reached $11,871 \mathrm{mg} \mathrm{kg}^{-1}$ wet weight (Rebelo et al., 2003).

Some studies have been performed in recent years to determine the extent of metal contamination in the biota of the CIEC (Table 2). Most of these studies have used fish as bioaccumulation models. Fernandez et al. (2014) compared metal concentrations in tissues from the fish species Mugil curema collected in the CIEC and in another estuary in the southeastern region of Brazil (Santos, Sao Paulo). The presence of $\mathrm{Pb}$ was not evaluated in that study, but $\mathrm{Cu}$ and $\mathrm{Zn}$ levels in the animals collected around Cananéia Island were found to be extremely high; average (ww) values were $406 \mathrm{mg} \mathrm{kg}^{-1}$ and $116 \mathrm{mg} \mathrm{kg}^{-}$ ${ }^{1}$, respectively. Unlike the concentrations that were found in oysters (Machado et al., 2002; Barros and Barbieri, 2012), these values were found to be above the maximum tolerance limits established for fishing products by Brazilian law (Brazil, 1965): they were $30.0 \mathrm{mg} \mathrm{kg}^{-1}$ in the case of $\mathrm{Cu}$ and $50.0 \mathrm{mg} \mathrm{kg}^{-1}$ in the case of $\mathrm{Zn}$. It is worth mentioning that, although $\mathrm{Cu}$ is an essential metal, its concentration in these animals was 13 times above legal limits. In addition, $\mathrm{Cu}$ levels in the fish from the CIEC were higher than the amount found in fish from the Santos Estuary $(282 \mathrm{mg}$ $\left.\mathrm{kg}^{-1}\right)$, a location that is known to be heavily impacted by industrial and port-related activities. However, the concentrations that were above recommended limits were found in the fishes' liver tissue; normally, muscle is used for human consumption.

Fernandez et al. (2014) found elements' concentrations in fish tissues comparable to those from an impacted estuary (Santos - São Vicente Estuary). A similar observation was also made by Azevedo et al. (2012b). The authors evaluated the presence of metals in tissues from two species of catfish (Cathorops spixii and Genidens genidens) and did not find significant differences in $\mathrm{Zn}$ concentrations between the animals collected from the two aforementioned estuaries. In another study, Azevedo et al. (2009a) identified the presence of $\mathrm{Fe}, \mathrm{Co}$, and $\mathrm{Zn}$ in tissues of $C$. spixii from the Mar de Cananéia channel. The animals collected in the CIEC had higher Fe levels than the animals collected in the Santos - São Vicente Estuary (4.84 $\mathrm{mg} \mathrm{kg}^{-1}$ and $3.08 \mathrm{mg} \mathrm{kg}^{-1}$, respectively). The authors attributed this difference to the more efficient metabolism that may have been developed by the $\mathrm{CIEC}$ animals, given the role of $\mathrm{Fe}$ as a micronutrient in biological systems. Among the other elements analyzed by Azevedo et al. (2009a) in the animals from the CIEC, selenium was found at an average concentration of $12.73 \mathrm{mg} \mathrm{kg}^{-1}(\mathrm{ww})$ a value much higher than the limit of $0.03 \mathrm{mg} \mathrm{kg}^{-1}$ established for solid foods in the Brazilian legislation (Brazil, 1965).

Other studies compared the presence of metals in CIEC fish to those from the Santos - São Vicente Estuary; however, higher levels in the animals from the industrialized area were the most common finding. Mercury concentrations in muscles of $C$. spixii from the Santos Estuary were higher than those found in fish from CIEC $\left(1.085 \mathrm{mg} \mathrm{kg}^{-1}\right.$ (ww) against $0.231 \mathrm{mg} \mathrm{kg}^{-1}(\mathrm{ww})$, respectively) (Azevedo et al., 2009b). In a further publication, Azevedo et al. (2012c) reported maximum $\mathrm{Hg}$ values in muscle $\left(0.19 \mathrm{mg} \mathrm{kg}^{-1}\right)$ and in liver tissue $\left(1.04 \mathrm{mg} \mathrm{kg}^{-1}\right)$ from C. spixii specimens collected in the Mar de Cananéia channel. Though fish liver is not commonly consumed by humans, the amount of $\mathrm{Hg}$ in this organ was found to exceed the levels recommended by both Brazilian law (ANVISA, 2013) and international agencies (FAO/WHO, 2004; EC, 2006). Recommended values are consistent across the agencies; the limits of mercury that are safe for human consumption are $0.5 \mathrm{mg} \mathrm{kg}^{-1}$ in non-predatory fish and $1.0 \mathrm{mg} \mathrm{kg}^{-1}$ in piscivorous fish. Thus, elevated mercury concentrations may be transferred to other levels of the tropic chain within the CIEC.

According to Azevedo et al. (2012a), the presence of $\mathrm{Hg}$ in the CIEC could be partially explained by the presence of an abandoned gold mine and a fertilizer factory located close to the northern portion of the estuary. However, $\mathrm{Hg}$ could also come from different sources, such as atmospheric transport (Fitzgerald et al., 1998), dispersion through suspended sediments via continental drainage (Mol et al., 2001), or migratory aquatic species tissues (Wiener and Spry, 1996). 
Table 2. Concentrations of metals and arsenic reported in biota of the Cananéia-lguape Estuarine Complex. Data represent mean \pm SD to wet weight basis (ww) expressed in $\mathrm{mg} \mathrm{kg}^{-1}$. The extreme values (minimum and maximum) are also presented. Action levels for human consumption established by different health agencies are also given (the exceedances are presented in bold).

\begin{tabular}{|c|c|c|c|c|c|c|c|c|c|c|c|}
\hline Species & $\mathbf{n}$ & As & Cd & $\mathrm{Cr}$ & $\mathrm{Cu}$ & $\mathrm{Fe}$ & $\mathrm{Hg}$ & $\mathrm{Hg}$ & $\mathbf{P b}$ & $Z n$ & Reference \\
\hline \multirow{2}{*}{$\begin{array}{l}\text { Crassostrea } \\
\text { brasiliana }\end{array}$} & 69 & & $\begin{array}{c}0.11 \\
(0.02- \\
0.22)\end{array}$ & & $\begin{array}{c}2.8 \\
(1.5- \\
7.7)\end{array}$ & & $\begin{array}{c}0.02 \\
(<\mathrm{DL}- \\
0.03)\end{array}$ & & $\begin{array}{c}0.8 \\
(0.04- \\
0.17)\end{array}$ & $\begin{array}{c}402 \\
(145- \\
844)\end{array}$ & $\begin{array}{l}\text { Machado et } \\
\text { al. (2002) }\end{array}$ \\
\hline & $\mathrm{NR}$ & & $<\mathrm{DL}$ & & $\begin{array}{l}0.2 \pm \\
0.002\end{array}$ & & & $\begin{array}{c}0.02 \pm \\
0.01\end{array}$ & $\begin{array}{c}0.24 \pm \\
0.01\end{array}$ & $\begin{array}{c}20.4 \pm \\
9.8\end{array}$ & $\begin{array}{c}\text { Barros and } \\
\text { Barbieri } \\
\text { (2012) }\end{array}$ \\
\hline $\begin{array}{l}\text { Anomalocardia } \\
\text { brasiliana }\end{array}$ & $\mathrm{NR}$ & & $\begin{array}{l}1.01 \\
(0.88- \\
1.46) \\
\end{array}$ & & & & & & & & Cruz (2014) \\
\hline $\begin{array}{l}\text { Genidens } \\
\text { genidens } \\
\text { (muscle) }\end{array}$ & 10 & & $\begin{array}{c}0.01 \\
(0.003- \\
0.01)\end{array}$ & & $\begin{array}{c}0.04 \\
(0.01- \\
0.07) \\
\end{array}$ & & $\begin{array}{c}0.21 \\
(0.01- \\
0.26)\end{array}$ & & $\begin{array}{c}0.06 \\
(0.03- \\
0.07) \\
\end{array}$ & $\begin{array}{c}0.01 \\
(0.01- \\
0.02) \\
\end{array}$ & $\begin{array}{l}\text { Azevedo et } \\
\text { al. (2012b) }\end{array}$ \\
\hline \multirow{4}{*}{$\begin{array}{l}\text { Cathorops spixii } \\
\text { (liver) }\end{array}$} & 5 & & & & & $\begin{array}{c}4,838 \\
(3,419- \\
5,501)\end{array}$ & $\begin{array}{c}0.25 \\
(0.25- \\
0.26)\end{array}$ & & & $\begin{array}{c}1.11 \\
(0.95- \\
1.21)\end{array}$ & $\begin{array}{l}\text { Azevedo et } \\
\text { al. (2009a) }\end{array}$ \\
\hline & 15 & & $\begin{array}{l}0.02- \\
1.24\end{array}$ & & $\begin{array}{l}1.08- \\
4.78\end{array}$ & & & & $\begin{array}{l}0.02- \\
0.58\end{array}$ & $\begin{array}{l}100- \\
850\end{array}$ & $\begin{array}{l}\text { Azevedo et } \\
\text { al. (2012a) }\end{array}$ \\
\hline & 20 & & & & & & 1.04 & & & & $\begin{array}{l}\text { Azevedo et } \\
\text { al. (2012c) }\end{array}$ \\
\hline & 225 & 0.01 & $\begin{array}{c}0.34 \\
(0.11- \\
1.58)\end{array}$ & $\begin{array}{l}10.21 \\
(0.08- \\
39.28)\end{array}$ & $\begin{array}{c}41.5 \\
(0.1- \\
146.7)\end{array}$ & & & $<0.09$ & $\begin{array}{c}0.86 \\
(0.11- \\
6.39)\end{array}$ & 243.82 & $\begin{array}{l}\text { Gusso- } \\
\text {-Choueri et } \\
\text { al. (2016) }\end{array}$ \\
\hline \multirow{3}{*}{$\begin{array}{l}\text { C. spixii } \\
\text { (muscle) }\end{array}$} & 152 & & & & & & $\begin{array}{c}0.1 \\
(<0.03- \\
0.35)\end{array}$ & & & & $\begin{array}{l}\text { Azevedo et } \\
\text { al. (2009b) }\end{array}$ \\
\hline & 60 & & & & & & $\begin{array}{c}0.08 \\
(0.02- \\
0.35)\end{array}$ & & & & $\begin{array}{l}\text { Azevedo et } \\
\text { al. (2011) }\end{array}$ \\
\hline & 225 & $\begin{array}{l}1.15 \\
(0.0- \\
5.7)\end{array}$ & $\begin{array}{c}4.54 \\
(<0.11- \\
13.6)\end{array}$ & 0.08 & 0.1 & & & $\begin{array}{c}119.53 \\
(<0.1- \\
339.3)\end{array}$ & $\begin{array}{l}14.64 \\
(<0.1- \\
73.2)\end{array}$ & $\begin{array}{c}23.07 \\
(9.1- \\
65.57)\end{array}$ & $\begin{array}{c}\text { Gusso- } \\
\text {-Choueri } \\
\text { et al. } \\
(2016,2018)\end{array}$ \\
\hline C. spixii (gills) & 15 & & $\begin{array}{l}0.001- \\
0.005\end{array}$ & & $\begin{array}{l}0.15- \\
0.83\end{array}$ & & & & $\begin{array}{l}0.04- \\
0.41\end{array}$ & $\begin{array}{l}145- \\
926\end{array}$ & $\begin{array}{l}\text { Azevedo et } \\
\text { al. (2012a) }\end{array}$ \\
\hline $\begin{array}{l}\text { Micropogonias } \\
\text { furnieri (muscle) }\end{array}$ & 11 & & & & & & $\begin{array}{c}0.24 \\
(0.11- \\
0.44)\end{array}$ & & & & $\begin{array}{l}\text { Curcho et al } \\
\text { (2009) }\end{array}$ \\
\hline $\begin{array}{l}\text { Mugil curema } \\
\text { (liver) }\end{array}$ & 156 & & & & $\begin{array}{c}406 \pm \\
182\end{array}$ & $\begin{array}{c}791 \pm \\
260\end{array}$ & & & & $\begin{array}{c}116 \pm \\
17\end{array}$ & \multirow{2}{*}{$\begin{array}{l}\text { Fernandez } \\
\text { et al. (2014) }\end{array}$} \\
\hline $\begin{array}{l}\text { M. curema } \\
\text { (kidney) }\end{array}$ & 149 & & & & $\begin{array}{c}6.6 \pm \\
2.3\end{array}$ & $\begin{array}{c}791 \pm \\
260\end{array}$ & & & & $59 \pm 11$ & \\
\hline
\end{tabular}


Continuation table 2.

\begin{tabular}{|c|c|c|c|c|c|c|c|c|c|c|c|}
\hline Action levels & $n$ & As & $\mathrm{Cd}$ & $\mathrm{Cr}$ & $\mathrm{Cu}$ & $\mathrm{Fe}$ & $\mathrm{Hg}$ & $\mathrm{Ni}$ & $\mathbf{P b}$ & $\mathrm{Zn}$ & Reference \\
\hline \multirow{5}{*}{ Fish species } & & 1.0 & 1.0 & 0.1 & 30.0 & & 0.5 & 5.0 & 2.0 & 50.0 & $\begin{array}{l}\text { Brazil } \\
(1965)\end{array}$ \\
\hline & & 1.0 & $\begin{array}{c}0.05 \text { to } \\
0.3\end{array}$ & & & & 0.5 & & 0.3 & & $\begin{array}{l}\text { ANVISA } \\
(2013)\end{array}$ \\
\hline & & 1.0 & 1.0 & & & & 1.0 & & 2.0 & & $\begin{array}{c}\text { FAO/WHO } \\
(2004)\end{array}$ \\
\hline & & & $\begin{array}{c}0.1 \text { to } \\
1.0\end{array}$ & & & & 0.5 & & 0.2 to 2 & & EC (2006) \\
\hline & & 1.0 & 0.05 & & & & 0.5 & & 0.3 & & $\begin{array}{c}\text { MERCOSUL } \\
(2011)\end{array}$ \\
\hline \multirow{2}{*}{$\begin{array}{l}\text { Bivalve } \\
\text { molluscs }\end{array}$} & & & 1.0 & & & & & & 1.5 & & EC (2006) \\
\hline & & 1.0 & 2.0 & & & & 0.5 & & 1.5 & & $\begin{array}{l}\text { MERCOSUL } \\
\text { (2011) }\end{array}$ \\
\hline
\end{tabular}

*Bioaccumulation tests using animals from Trapandé Bay and exposed to $\mathrm{CIEC}$ sediments; $\mathrm{NR}=$ Not reported; $\mathrm{DL}=$ Detection limit.

In a recent paper, Gusso-Choueri et al. (2018) reported the presence of high levels of metals and As in muscle from C. spixii specimens collected in the Mar de Cananéia channel. These concentrations exceed the action levels for human consumption (Table 2). The maximum concentrations (wet weight basis) of metals in tissues from C. spixii specimens from the CIEC were reported by Gusso-Choueri et al. (2016). The levels found in the liver were $1.58 \mathrm{mg} \mathrm{kg}^{-1}$ of $\mathrm{Cd}$, $39.28 \mathrm{mg} \mathrm{kg}^{-1}$ of $\mathrm{Cr}, 146.70 \mathrm{mg} \mathrm{kg}^{-1}$ of $\mathrm{Cu}, 6.39 \mathrm{mg} \mathrm{kg}^{-1}$ of $\mathrm{Pb}$ and $537.84 \mathrm{mg} \mathrm{kg}^{-1}$ of $\mathrm{Zn}$. In muscle, the maximum concentrations (ww) found were $5.73 \mathrm{mg} \mathrm{kg}^{-1}$ of As, $13.64 \mathrm{mg} \mathrm{kg}^{-1}$ of $\mathrm{Cd}, 73.22 \mathrm{mg} \mathrm{kg}^{-1}$ of $\mathrm{Pb}$ and $65.57 \mathrm{mg}^{-1}$ $\mathrm{kg}^{-1}$ of $\mathrm{Zn}$. Arsenic, cadmium and lead values were found to be above the limits recommended by both national and international regulatory agencies (Table 2), whose recommended limits are $1.0,0.2,0.05 \mathrm{mg}$ $\mathrm{kg}^{-1}$, respectively (FAO/WHO, 2004; EC, 2006; ANVISA, 2013). The reported concentrations are alarming, particularly for having been found in the edible portions of a species commonly consumed in the region.

In addition to their presence in commercial species, metals were also found in Sotalia guyanensis cetaceans (Salgado, 2015) and Chelonia mydas turtles (Barbieri, 2009) from the CIEC. The main metals found in the liver of the S. guyanensis (ww) were $\mathrm{Zn}(37.7 \mathrm{mg}$ $\left.\mathrm{kg}^{-1}\right), \mathrm{Pb}\left(1.94 \mathrm{mg} \mathrm{kg}^{-1}\right), \mathrm{Cu}\left(14.18 \mathrm{mg} \mathrm{kg}^{-1}\right), \mathrm{Cd}(0.07 \mathrm{mg}$ $\left.\mathrm{kg}^{-1}\right)$ and $\mathrm{Cr}\left(2.84 \mathrm{mg} \mathrm{kg}^{-1}\right)$; the concentrations of $\mathrm{Pb}$ were higher than those found in livers of Sotalia fluviatilis off the coast of Ceará, northeast Brazil (MonteiroNeto et al., 2003), while the concentrations of Cd were low and comparable in both studies. According to Salgado (2015), Pb showed the highest mean values ever described for the species. Regarding Chelonia mydas, elevated levels of $\mathrm{Cu}$ and $\mathrm{Ni}$ were found in the liver, with average dry weight basis values of $39.9 \mathrm{mg}$ $\mathrm{kg}^{-1}$ and $0.28 \mathrm{mg} \mathrm{kg}^{-1}$, respectively. The highest levels of $\mathrm{Cd}$ were found in the kidneys of these animals; the average concentration was $2.18 \mathrm{mg} \mathrm{kg}^{-1}$ (dry weight basis). Lead concentrations were relatively high in both the liver and the kidneys, with average values of 0.37 and 0.56 (dw), respectively (Barbieri, 2009). In general, concentrations were higher than those observed in sea green turtles (C. mydas) and hawksbill turtles (Eretmochelys imbricata) from northern coast of Bahia (Macêdo et al., 2015), but comparable or lower than those detected by Silva et al. (2014) in C. mydas from the $S$ and SE coast of Brazil. In the case of APA-CIP, although these animals were found in the estuary, the sources of contamination may have been elsewhere, since turtles migrate long distances between feeding areas.

\section{EFFECTS OF STRESSORS}

\section{SEDIMENT TOXICITY: ECOTOXICOLOGICAL STUDIES}

Since 2010, the São Paulo State Environmental Agency (CETESB) has been monitoring the sediment quality of two water bodies in the CIEC (three stations in the Mar Pequeno channel and three in the Mar de Cananéia channel) through biannual samplings. This monitoring includes analyses based on specific indices for the microbiological, chemical and ecotoxicological quality of coastal sediments. The ecotoxicological assessment consists of chronic toxicity assays 
with embryos of the sea urchin Lytechinus variegatus (sediment/water interface) and acute toxicity assays with the amphipod Leptocheirus plumulosus (whole sediment). According to the percent of affected organisms in the ecotoxicological assays, sediments were classified as presenting "very good," "good," "fair," "poor," or "very poor" quality. The 2015's CETESB's annual report of the quality of saltwater and brackish waters of the state of Sao Paulo (relative to data collected in 2014), sediments from the three sampling stations located in the Mar Pequeno channel presented acute toxicity and the sediment quality was considered "very poor" (mortality of L. plumulosus $\geq$ 50\%). Regarding Mar de Cananéia channel, acute toxicity was not observed. However, sediments from two stations showed chronic toxicity and the quality of the sediments was respectively classified as "fair" (51$70 \%$ of normal $L$. variegatus larvae) and "very poor" (normal larvae < 25\%) (CETESB, 2015).

Previous assessments performed by the CETESB showed that the quality of sediments from the Mar de Cananéia channel was occasionally classified as "poor" (for example, in 2010). In 2011, sediments did not exhibit evidence of toxicity, but in 2012 sediments from all the sampling stations of Mar de Cananéia channel were classified as "very poor". There was evidence of L. plumulosus mortality above $50 \%$, and less than $25 \%$ of $L$. variegatus larvae were normal (CETESB, 2012; 2013). In 2013, the quality of sediments from the Mar Pequeno channel was considered "good" (CETESB, 2014). In the second half of 2013, the concentration of $\mathrm{Pb}$ was $30.7 \mathrm{mg} \mathrm{kg}^{-1}$ in a sample located in the Mar Pequeno channel; this concentration is above ISQG for coastal sediments (CCME, 2002). As for the Mar de Cananéia channel, chronic toxicity was reported for one of the three tested sediments and the sediment quality was considered "poor". Furthermore, the CETESB report (2014) notes the presence of metals with values below but close to ISQG.

In broader ecotoxicological studies, surface sediment toxicities in the Mar Pequeno and the Mar de Cananéia channel have also been conducted (Araújo, 2014; Cruz et al., 2019). In these studies, sediment samples collected close to the mouth of the Valo Grande Canal and from the central region of the Mar Pequeno channel (close to the Pedra do Tombo region) exhibited acute toxicity for T. viscana during the rainy seasons. Araújo (2014) points to the influence of climatic factors on contaminated material transport. The author found higher toxicity levels in the sediments that were more strongly influenced by the Valo Grande Canal, areas which themselves respond synchronously to the increase in RIR flows during periods of high rainfall in the Ribeira Valley. Sediments from the Mar de Cananéia channel affected the embryo-larval development of $L$. variegatus during the rainy seasons (Cruz et al., 2019), results which also represent chronic toxicity. Besides, the samples collected during the dry season were more toxic in the Mar Pequeno channel, while those collected during the rainy season were more toxic in the Mar de Cananéia channel. This difference suggests that fine suspended particles from the RIR are transported into the southern portion of the CIEC; as previously discussed in the section "exposure characterization to the stressors" of this review.

In another ecotoxicological study at Mar de Cananéia channel, Cruz et al. (2014) found acute and chronic toxicity in surface sediments from areas surrounding the southern portions of Cananéia Island and Comprida Island. The acute toxicity was characterized by the lethal effects on the burrowing amphipod Tiburonella viscana, in stations located close to the urban center. Then, toxicity was attributed to sources located in the city of Cananéia. All of the sediment samples collected from a total of eight sampling sites exhibited chronic toxicity for the benthic copepod Nitocra sp. (effects on organism fecundity); the authors suggested that metals from the RIR were the cause of chronic toxicity.

As previously mentioned, some studies have associated changes in the hydrological regime of the RIR basin with seasonality (Corsi and Landim, 2003; Costa et al., 2009), with increased amounts of metals carried to CIEC during the rainy season (Cunha et al., 2007). Since the depositional areas along the CIEC may change throughout the year, the areas defined as having more extensive contaminated sediment deposition may change seasonally; and so do the areas of risk to the biota may change seasonally as well. The literature showed that toxicity is mainly associated with fine sediments, such as those collected at the Mar Pequeno and the Mar de Cananéia. Some authors suggested that metals can be transported southward (Tramonte et al., 2018; Cruz et al., 2019), and our analysis of the published information allow 
us to conclude that depositional areas in CIEC change over time, being influenced by rainfall indices and the interaction between inputs of freshwater and currents waves. Therefore, greater freshwater inflow may influence the transport of sediments and contaminants, as the maximum depositional areas tend to migrate towards south during the rainy season.

In addition to the short-term and long-term lethal effects, the adverse effects of metals may cause damages at the molecular, biochemical, cellular, and physiological levels. Therefore, biological responses to environmental aggressions should not be identified only based on the structure of the ecosystem (such as biological populations and communities), but also at more basal levels of organization, such as intracellular biochemical reactions (Bayne et al., 1985). In this way, greater potential damages to biological organization can be anticipated.

In the $\mathrm{CIEC}$, biochemical biomarkers were used by Azevedo et al. (2009b) on C. spixii collected in the Mar de Cubatão and Mar de Cananéia in order to assess exposure and the possible effects of metals. No changes to metallothionein content, lipid peroxidation (LPO), or $\delta$-Aminolevulinic acid dehytrase enzyme ( $\delta$-ALAD) activity were observed. Given these results and the lack of significant $\mathrm{Hg}$ contamination in fish tissues $\left(0.09 \mathrm{mg} \mathrm{kg}^{-1} \mathrm{ww}\right.$ ), the authors did not consider the area to be impacted. Araújo (2014) analyzed biochemical biomarkers in the Callinectes danae crab collected in the CIEC, and the crustaceans exhibited changes in glutathione peroxidase (GPx) activity, glutathione S-transferase (GST) and LPO, as well as DNA damage (strand breaks). In an integrated multivariate approach to estuarine sediment contamination, the authors found that metal concentrations in these matrices are enough to produce negative effects on the native biota, especially due to the activation of depuration processes and the secondary production of reactive oxygen species. Metal contamination may have activated the antioxidant system, causing lipid peroxidation in the tissues of $C$. danae. They also affirmed that the animals collected during the winter exhibited more enzyme activity than those collected during the summer, thus providing evidence that seasonality has a strong influence on biomarker response in the animals studied. According to the study, the sediments collected in the central areas of the Mar Pequeno and the Mar de
Cananéia exhibited higher metal concentrations. The crabs collected in the Mar de Cananéia channel experienced a more substantial response to the biomarkers during the summer, as was observed through LPO and DNA damage. Meanwhile, organisms from the central area of the Mar Pequeno channel exhibited similar qualitative results in the winter, with an increase in GPx enzyme activity. The study also found acetylcholinesterase (AChE) inhibition during the summer. According to Devi and Fingerman (1995), AChE inhibition has great potential for serving as a biomarker for metal pollution. However, Araujo (2014) also stated this result could be caused by the use of pesticides along RIR basin.

In a more recent study assessing the environmental quality of the CIEC, a set of analyses was used in which biochemical biomarkers served as a tool in different organs from C. spixii (Gusso-Choueri et al., 2015). The authors analyzed GST, GPx and AChE activity and also quantified metallothioneins, GSH, LPO and DNA damage. They concluded that $\mathrm{Pb}$ may be highly relevant in the neurotoxicity experienced by $C$. spixii, as shown by the AChE activity in contaminated fish. In addition, they observed seasonal differences in the adverse effects on fish in the northern section of the CIEC relative to the southern section. During the dry season, metal concentrations in the organisms and their responses to biomarkers were greater in the southern section of the CIEC, a finding that reflects the influence of the city of Cananéia. However, during the rainy season, the most highly affected organisms were those collected close to the Valo Grande Canal, in the central area of the Mar Pequeno channel (the northern section), and from the Mar de Cananéia channel close to its meeting with the Mar Pequeno. These results reflect the influence of the Ribeira de Iguape River on toxicity.

The rainy period was also influential on the results of cytogenotoxicity studies on fish collected at the Mar de Cananéia channel. Kirschbaum et al. (2009) evaluated erythrocytes from Centropomus parallelus and found nuclear abnormalities (NAs) to be slightly higher in the summer (rainy season) than in the winter (dry season). However, these abnormalities were not high enough for the location to be considered impacted. Azevedo et al. (2012d) also identified higher NA frequencies (\%) in C. spixii during the summer. In light of the evidence outlined herein, it is possible 
that metals are still being transported from the RIR to the southern portion of the CIEC, particularly during periods of high rainfall.

Although the entire region of the CIEC has often received a blanket description of an area of reference for environmental studies (Azevedo et al., 2009a; Azevedo et al., 2009b; Kirschbaum et al., 2009; Azevedo et al., 2011; Azevedo et al., 2012a; Azevedo et al., 2012c), the integration of data on metal sediment contamination and on the effects of this contamination on biological systems indicates that some portions of the estuary are clearly impacted. Furthermore, even if contaminants are at only moderate levels, they are still harmful to biota in many instances, such as citogenotoxic and biochemical effects. In these cases, in addition to assessing the presence of stressors, such as metals the use of biomarkers provides useful information for protective management of CIEC.

Overall, the variations in toxicity relative to seasonality provide evidence of the influence of abiotic parameters on the bioavailability of contaminants in aquatic systems, since $\mathrm{pH}$, salinity and temperature can all modify the bioavailability and/or the uptake of contaminants in these systems. The variations in toxicity also depend on spatial variation, which can occur as a function of the distribution and deposition of sediments. The samples with greater amounts of organic material and finer-grained sediment fractions (silt and clay) exhibited higher concentrations of most of the elements found in the CIEC sediments. Thus, any considerations regarding the environmental quality of the Cananéia-Iguape Estuarine Complex should consider the space-time variability of contamination.

\section{CONCLUSIONS}

As outlined in this review, studies on the CIEC suggest that contamination seems to be increasing in the region as a result of different sources. A set of contamination sources within the CIEC is close to the urban center of the city of Cananéia. On the other hand, metals associated with suspended fine particles are clearly introduced into the system through the Valo Grande Canal. This association indicates that the former mining sites are the primary sources of metals to the CIEC. Both particulate transport across the estuary and resuspension processes are influenced by tidal movements and contribute to differences in surface sediment composition and toxicity, though they are not always established by local inputs. Therefore, areas with a higher presence of metals in the sediments are not always those, which are closest to the source.

The data available provides evidence of significant variation in metal concentrations between the northern and southern sections of the estuary. Concentrations of metals are clearly higher in the north portion of the estuarine complex. In the southern section, metals in sediments and biota of Mar de Cananéia are higher than Mar de Cubatão. This finding may be associated with the circulation of water within the estuary, which favors the sedimentation of particles and contaminants in the Mar de Cananéia channel, and its transport south during short-term episodes of extreme rainfalls.

An essential factor to highlight in this environmental protection area is that, though the CIEC is not highly polluted, some areas exhibit metal contaminations, which exceed sediment quality guidelines (CCME, 2002). Also, this finding was represented in the contamination found in species of fish that most commonly live on the bottom of the estuary channels but which may inhabit other strata, albeit on a small scale. The metal concentrations above the limits recommended for human consumption that were found in commonly consumed species are alarming and reflect the potential risk to the local human population. In some portions of the CIEC, the bioavailability of metals found in the sediments was reflected also through the ecotoxicological data. In these regions, metals are not only available to the point of causing negative effects on the biota, but can combine with other factors, such as ammonia, and produce toxicity. Moreover, toxicity tends to be associated with muddy sediments, indicating that depositional areas are of main concern within the estuarine system.

Marine protected areas (MPA) have been established as an important strategy to preserve ecosystems and to avoid negative impacts due to anthropic activities (Day et al., 2012). Brazilian legislation has also placed the CIP-PA in a protection category that should achieve a sustainable balance between the anthropic uses of the natural resources and the protection of the natural ecosystems (Moraes, 2004). However, occurrence of toxicity and metal 
contamination in CEIC sediments represent threats to CIP-PA conservation objectives and indicate that the protection status is not being totally achieved. In fact, designating an area as protected, by itself, cannot ensure its protection; thus, pollution has been detected in MPAs (Terlizzi et al., 2004; Araujo et al., 2013; Rodrigues et al., 2013). This kind of situation has been discussed in recent years (Barber et al., 2004; Cicin-Sain and Belfiore, 2005; Lausche, 2011); and as Jameson et al. (2012) argue: "an area is not magically or instantaneously 'protected' via an MPA designation process". Uncontrollable external pollutant sources are not situated in side MPA, and this disturb can affect the ecosystems situated within these areas (Kelleher, 1999). Such sources are frequently beyond the direct control of MPA managers and their impacts are not easily mitigated. Under such conditions, lack of effectiveness in MPAs may occur, and when the management of a protected area does not properly address the surrounding areas, protection may not be successful. According to Salm et al. (2000), one of the first steps taken is to design an appropriate management plan for controlling the sources and avoiding pollution should be developed. Such plan is required to guarantee the protection of CIP-PA, by the development of policies to control the contamination sources located upstream (especially former mining areas) and within the $\mathrm{CIEC}$, such as those situated in the cities of Iguape, Cananeia and Ilha Comprida (sewage, urban drainage, marinas, among others).

The MPA plans must go beyond identifying sources of pollution and must search for information on potential pollutants, their concentrations, and their biological effects. The ecotoxicological data are limited to the point that ecological consequences of metals on biodiversity and productivity inside this area are still unknown, likewise of the majority of the MPAs around the world (Abessa et al., 2018). Furthermore, the current review highlights the importance of further research in this MPA, which include the use of biomarkers and others ecotoxicological tools, in order to associate the presence of contaminants with negative biological effects. Such tools provide information for making sound decisions regarding environmental health status and they support the development of management plan for the strategy of protection.

\section{ACKNOWLEDGEMENTS}

The authors acknowledge São Paulo State Research Foundation (FAPESP) [processes 2009/52762-6] and National Council for Scientific and Technological Development (CNPq) [processes 142622/2011-7] for the financial support.

\section{AUTHOR CONTRIBUTIONS}

F.C.P: Conceptualization; Data curation; Investigation; Writing - original draft; Writing - review \& editing;

D.M.S.A.: $\quad$ Supervision; Funding acquisition; Methodology; Project administration; Writing - review \& editing.

\section{REFERENCES}

ABDULLA, A., OBURA, D., BERTZKY, B. \& SHI, Y. 2013. Marine Natural Heritage and the World Heritage List: Interpretation of World Heritage criteria in marine systems, analysis of biogeographic representation of sites, and a roadmap for addressing gaps. Gland, Switzerland: IUCN.

ABESSA, D. M. S., ALBUQUERQUE, H. C., MORAIS, L. G., ARAÚJO, G. S., FONSECA, T. G., CRUZ, A. C. F., CAMPOS, B. G., CAMARGO, J. B. D. A., GUSSO-CHOUERI, P. K., PERINA, F. C., CHOUERI, R. B. \& BURUAEM, L. M. 2018. Pollution status of marine protected areas worldwide and the consequent toxic effects are unknown. Environmental Pollution, 243, 1450-1459.

ABESSA, D. M. S., CARR, R. S., SOUSA, E. C. P. M., RACHID, B. R. F., ZARONI, L. P., GASPARRO, M. R., PINTO, Y. A., BÍCEGO, M. C., HORTELLANI, M. A., SARKIS, J. E. S. \& MUNIZ, P. 2008. Integrative ecotoxicological assessment of contaminated sediments in a complex tropical estuarine system. In: HOFER, T. N. (ed.). Marine Pollution: New Research. New York, USA: Nova Science Publishers.

ABESSA, D. M. S., MORAIS, L. G., PERINA, F. C., DAVANSO, M. B., BURUAEM, L. M., MARTINS, L. M. P., SÍGOLO, J. B. \& RODRIGUES, V. G. S. 2012. Water and sediment toxicity in a river affected by former mining residues. Mundo da Saude, 36(4), 610-618.

ABESSA, D. M. S., MORAIS, L. G., PERINA, F. C., DAVANSO, M. B., RODRIGUES, V. G. S., MARTINS, L. M. P. \& SÍGOLO, J. B. 2014 Sediment geochemistry and climatic influences in a river influenced by former mining activities: the case of Ribeira de Iguape River, SP-PR, Brazil. Open Journal of Water Pollution and Treatment, 1, 43-53.

AGUIAR, V. M. C., BRAGA, E. S. \& BAPTISTA-NETO, J. A. 2008. Heavy metal assessment in two subtropical estuarine systems in the State of São Paulo, Brazil. In: HOFER, T. N. (ed.). Marine Pollution: New Research. New York, USA: Nova Science Publishers.

ALLEN, H. E., FU, G. \& DENG, B. 1993. Analysis of Acid-Volatile Sulfide (AVS) and Simultaneously Extracted Metals (SEM) for the estimation of potential toxicity in aquatic sediments. Environmental Toxicology and Chemistry, 12(8), 1441-1453. 
ALLERT, A. L., FAIRCHILD, J. F., SCHMITT, C. J., BESSER, J. M., BRUMBAUGH, W. G. \& OLSON, S. J. 2009. Effects of mining-derived metals on riffle-dwelling benthic fishes in Southeast Missouri, USA. Ecotoxicology and Environmental Safety, 72(6), 1642-1651.

AMADO-FILHO, G. M., SALGADO, L. T., REBELO, M. F., REZENDE, C. E., KAREZ, C. S. \& PFEIFFER, W. C. 2008. Heavy metals in benthic organisms from Todos os Santos Bay, Brazil. Brazilian Journal of Biology, 68(1), 95-100.

AMORIM, E. P., FAVARO, D. I. T., BERBEL, G. B. B. \& BRAGA, E. S. 2008. Assessment of metal and trace element concentrations in the Cananéia estuary, Brazil, by neutron activation and atomic absorption techniques. Journal of Radioanalytical and Nuclear Chemistry, 278(2), 485-489.

ANKLEY, G. T., KATKO, A. \& ARTHUR, J. W. 1990. Identification of ammonia as an important sediment-associated toxicant in the lower fox River and green bay, Wisconsin. Environmental Toxicology and Chemistry, 9, 313-322.

ANKLEY, G. T., SCHUBAUER-BERIGAN, M. K. \& HOKE, R. A. 1992. Use of toxicity identification evaluation techniques to identify dredged material disposal options: a proposed approach. Environmental Management, 16, 1-6.

ANVISA (Agência Nacional de Vigilância Sanitária). 2013. Resolução RDC $n^{\circ}$ 42, de 29 de Agosto de 2013. Dispõe sobre o Regulamento Técnico MERCOSUL sobre limites máximos de Contaminantes Inorgânicos em Alimentos: MERCOSUL/GMC/ RES. N ${ }^{\circ}$ 12/11. Brasília, Brazil: ANVISA.

APHA (American Public Health Association). 1999. Standard Methods for the Examination of Water and Wastewater. 15th ed., pp. 1134. Washington, DC, USA: American Water Works Association/Water Pollution Control Federation.

ARA, K. 2004. Temporal variability and production of the planktonic copepod community in the Cananéia Lagoon estuarine system, Brazil. Zoological Studies, 43(2), 179-186.

ARAÚJO, G. S. 2014. Geochemical analyzes and ecotoxicological responses to assess the environmental quality in an estuarine protected area. PhD. São Paulo University. Available at: http://www.teses.usp.br/teses/disponiveis/21/21134/tde08042015-151309/en.php [Accessed dia Mês. ANO].

ARAUJO, G. S., MOREIRA, L. B., MORAIS, R. D., DAVANSO, M. B., GARCIA, T. F., CRUZ, A. C. F. \& ABESSA, D. M. S. 2013. Ecotoxicological assessment of sediments from an urban marine protected area (Xixova-Japui State Park, SP, Brazil). Marine Pollution Bulletin, 75(1-2), 62-68.

AZEVEDO, J. S., FERNANDEZ, W. S., FARIAS, L. A., FÁVARO, D. T. I. \& BRAGA, E. S. 2009a. Use of Cathorops spixii as bioindicator of pollution of trace metals in the Santos Bay, Brazil. Ecotoxicology, 18(5), 577-586.

AZEVEDO, J. S., SERAFIM, A., COMPANY, R., BRAGA, E. S., FÁVARO, D. I. \& BEBIANNO, M. J. 2009b. Biomarkers of exposure to metal contamination and lipid peroxidation in the benthic fish Cathorops spixii from two estuaries in South America, Brazil. Ecotoxicology, 18(8), 1001-1010.

AZEVEDO, J. S., BRAGA, E. S., FAVARO, D. T., PERRETTI, A. R., REZENDE, C. E. \& SOUZA, C. M. M. 2011. Total mercury in sediments and in Brazilian Ariidae catfish from two estuaries under different anthropogenic influence. Marine Pollution Bulletin, 62(12), 2724-2731.
AZEVEDO, J. S., HORTELLANI, M. A. \& SARKIS, J. E. D. S. 2012a. Accumulation and distribution of metals in the tissues of two catfish species from Cananéia and Santos-São Vicente estuaries. Brazilian Journal of Oceanography, 60, 463-472.

AZEVEDO, J. S., SARKIS, J. E. S., HORTELLANI, M. A. \& LADLE, R. J. 2012b. Are Catfish (Ariidae) effective bioindicators for $\mathrm{Pb}, \mathrm{Cd}$, $\mathrm{Hg}$, Cu and Zn?. Water, Air, and Soil Pollution, 223, 3911-3922.

AZEVEDO, J. S., SARKIS, J. E. S., OLIVEIRA, T. A. \& ULRICH, J. C. 2012c. Tissue-specific mercury concentrations in two catfish species from the Brazilian coast. Brazilian Journal of Oceanography, 60(2), 209-217.

AZEVEDO, J. S., BRAGA, E. S. \& RIBEIRO, C. A. O. 2012d. Nuclear abnormalities in erythrocytes and morphometric indexes in the catfish Cathorops Spixii (Ariidae) from different sites on the southeastern Brazilian coast. Brazilian Journal of Oceanography, 60(3), 323-330.

BARBER, C. V, MILLER, K. R. \& BONESS, M. 2004. securing protected areas in the face of global change: issues and strategies. Gland, Switzerland and Cambridge, UK: IUCN.

BARBIERI, E. 2009. Concentration of heavy metals in tissues of green turtles (Chelonia mydas) sampled in the Cananéia estuary, Brazil. Brazilian Journal of Oceanography, 57(3), 243248.

BARBIERI, E., MARQUEZ, H. L. A., CAMPOLIM, M. B. \& SALVARANI, P. I. 2014. Avaliação dos impactos ambientais e socioeconômicos da aquicultura na região Estuarina-Lagunar de Cananéia, São Paulo, Brasil. Revista de Gestão Costeira Integrada, 14(3), 385-398.

BARCELLINI, V. C., MOTTA, F. S., MARTINS, A. M. \& MORO, P. S. 2013. Recreational anglers and fishing guides from an estuarine protected area in southeastern Brazil: socioeconomic characteristics and views on fisheries management. Ocean \& Coastal Management, 76, 23-29.

BARCELLOS, R. L., CAMARGO, P. B., GALVAO, A. \& WEBER, R. R. 2009. Sedimentary organic matter in cores of the CananeiaIguape Lagoonal-Estuarine System, Sao Paulo State, Brazil. Journal of Coastal Research, 56spe, 1335-1339.

BARRERA-ALBA, J. J., GIANESELLA, S. M. F., SALDANHA-CORRÊA, F. M. P. \& MOSER, G. A. O. 2007. Influence of an artificial channel in a well-preserved sub-tropical estuary. Journal of Coastal Research, 50spe, 1137-1141.

BARROS, D. \& BARBIERI, E. 2012. Analysis of occurrence of metals: $\mathrm{Ni}, \mathrm{Zn}, \mathrm{Cu}, \mathrm{Pb}$ and $\mathrm{Cd}$ in oysters (Crassostrea brasiliana) and sediment collected in the Cananeia Estuary-SP (Brazil). Mundo da Saude, 36(4), 635-642.

BAY, S. M., GREENSTEIN, D. J., LAU, S. L., STENSTROM, M. K. \& KELLEY, C. G. 1996. Toxicity of dry weather flow from the Santa Monica Bay watershed. Bulletin of the Southern California Academy of Sciences, 95, 33-45.

BAYNE, B. L., BROWN, D. A., BURNS, K., DIXON, D. R., IVANOCI, A., LIVINGSTONE, D. R., LOWE, D. M., MOORE, M. N., STEBBING, A. R. D. \& WIDDINGS, J. 1985. The Effects of stress and pollution on marine animals. New York, USA: Praeger.

BECEGATO, J. L. \& SUGUIO, K. 2007. Impacto ambiental antrópico na APA (Área de Proteção Ambiental) da Ilha Comprida (SP): da pré-história à atualidade. Revista UnG - Geociências, 6(1), 107-117. 
BELMONTE, A. M. C. \& BELTRÁN, F. S. 2001. Flood events in Mediterranean ephemeral streams (ramblas) in Valencia region, Spain. Catena, 45(3), 229-249.

BENEDICTO, J., RODRIGUEZ, C., MARTINEZ-GOMEZ, C., GUERRERO, J. \& JORNET, A. 2008. Metal contamination in Portman Bay (Murcia, SE Spain) 15 years after the cessation of mining activities. Ciencias Marinas, 34(3), 389-398.

BERNARDES, M. E. C. \& MIRANDA, L. B. 2001. Circulação estacionária e estratificação de sal em canais estuarinos: simulação com modelos analíticos. Brazilian Journal of Oceanography, 49(1-2), 115-132.

BESSER, J. M., BRUMBAUGH, W. G., ALLERT, A. L., POULTON, B. C., SCHMITT, C. J. \& INGERSOLL, C. G. 2009. Ecological impacts of lead mining on Ozark streams: Toxicity of sediment and pore water. Ecotoxicology and Environmental Safety, 72(2), 516-526.

BRADSHAW, A. D. 1997. Restoration of mined lands-using natural processes. Ecological Engineering, 8(4), 255-269.

BRASIL. 1965. Normas reguladoras do emprêgo de aditivos para alimentos. Decreto $n^{\circ} 55871$, de 26 de março de 1965. Modifica o Decreto no 50.040, de 24 de janeiro de 1961, referente a normas reguladoras do emprego de aditivos para alimentos, alterado pelo Decreto n०691, de 13 de março de 1962. Diário Oficial da União, Brasília, DF, Brazil, 09 abr. 1965, Seção 1.

BULL, L., KIRKBY, M., SHANNON, J. \& HOOKE, J. 2000. The impact of rainstorms on floods in ephemeral channels in southeast Spain. Catena, 38(3), 191-209.

BUSCHLE, B. N., PALMEIRO, J. K., SADE, Y. B., MELO, V. F., ANDRADE, M. G. \& BATISTA, A. H. 2010. Kinetics of lead release from soils in heavy metal mining and metallurgy area. Revista Brasileira de Ciência do Solo, 34(6), 1864-1874.

CAMPOS, B. G., CRUZ, A. C. F., BURUAEM, L. M., RODRIGUES, A. P. C., MACHADO, W.T.V \& ABESSA, D. M. S. 2016. Using a tiered approach based on ecotoxicological techniques to assess the ecological risks of contamination in a subtropical estuarine protected area. The Science of the Total Environment, 544, 564-73.

CAPORALE, A. G. \& VIOLANTE, A. 2016. Chemical processes affecting the mobility of heavy metals and metalloids in soil environments. Current Pollution Reports, 2, 1527.

CARR, R. S., MONTAGNA, P. A., BIEDENBACH, J. M., KALKE, R., KENNICUTT, M. C., HOOTEN, R. \& CRIPE, G. 2000. Impact of storm-water outfalls on sediment quallity in corpus Christi Bay, Texas, USA. Environmental Toxicology and Chemistry, 19(3), 561-574.

CCME (Canadian Council of Ministers of the Environment). 2002. Canadian sediment quality guidelines for the protection of aquatic life: summary tables. Winnipeg, Canadian: CCME. Available at: http://st-ts.ccme.ca/en/index.html [Accessed 11 July. 2019].

CETESB (Companhia de Tecnologia e Saneamento Ambiental). 2000. Relatório de qualidade das águas interiores do Estado de São Paulo 1999. São Paulo, Brasil: CETESB. Available at: http://aguasinteriores.cetesb.sp.gov.br/publicacoes-e-relatorios/ [Accessed 24 August. 2019].

CETESB (Companhia de Tecnologia e Saneamento Ambiental). 2003. Relatório de Qualidade das Águas Interiores do Estado de São Paulo 2002, vol. 1. São Paulo, Brasil: CETESB. Available at: http://aguasinteriores.cetesb.sp.gov.br/publicacoes-erelatorios/ [Accessed 24 August. 2019].
CETESB (Companhia de Tecnologia e Saneamento Ambiental). 2005. Relatório de Qualidade das Águas Interiores do Estado de São Paulo 2004. São Paulo, Brasil: CETESB. Available at: http://aguasinteriores.cetesb.sp.gov.br/publicacoes-e-relatorios/ [Accessed 24 August. 2019].

CETESB (Companhia de Tecnologia e Saneamento Ambiental). 2007. Relatório de Qualidade das Águas Interiores do Estado de São Paulo 2006. São Paulo, Brasil: CETESB. Available at: http://aguasinteriores.cetesb.sp.gov.br/publicacoes-e-relatorios/ [Accessed 24 August. 2019].

CETESB (Companhia de Tecnologia e Saneamento Ambiental). 2010a. Inventário estadual de resíduos sólidos domiciliares 2010. São Paulo, Brasil: CETESB. Available at: http://residuossolidos.cetesb.sp.gov.br/residuos-solidos/residuos-urbanos-saude-construcao-civil/publicacoes-e-relatorios/ [Accessed 24 August. 2019].

CETESB (Companhia de Tecnologia e Saneamento Ambiental). 2010b. Qualidade das águas superficiais no Estado de São Paulo 2009. São Paulo, Brasil: CETESB. Available at: http:// aguasinteriores.cetesb.sp.gov.br/publicacoes-e-relatorios/ [Accessed 24 August. 2019].

CETESB (Companhia de Tecnologia e Saneamento Ambiental). 2012. Qualidade das águas superficiais no Estado de São Paulo 2011. São Paulo, Brasil: CETESB. Available at: http:// aguasinteriores.cetesb.sp.gov.br/publicacoes-e-relatorios/ [Accessed 24 August. 2019].

CETESB (Companhia de Tecnologia e Saneamento Ambiental). 2013. Qualidade das águas superficiais no Estado de São Paulo 2012. São Paulo, Brasil: CETESB. Available at: http:// aguasinteriores.cetesb.sp.gov.br/publicacoes-e-relatorios/ [Accessed 24 August. 2019].

CETESB (Companhia de Tecnologia e Saneamento Ambiental). 2014. Qualidade das águas salinas e salobras no Estado de São Paulo 2013. II. Parte do Relatório de Águas Superficiais São Paulo, Brasil: CETESB. Available at: http://aguasinteriores.cetesb.sp.gov.br/publicacoes-e-relatorios/ [Accessed 24 August. 2019].

CETESB (Companhia de Tecnologia e Saneamento Ambiental). 2015. Qualidade das águas salinas e salobras no Estado de São Paulo 2014. II. Parte do Relatório de Águas Superficiais São Paulo, Brasil: CETESB. Available at: http://aguasinteriores.cetesb.sp.gov.br/publicacoes-e-relatorios/ [Accessed 24 August. 2019].

CHAPMAN, P. M. \& WANG, F. Y. 2001. Assessing sediment contamination in estuaries. Environmental Toxicology and Chemistry, 20(1), 3-22.

CHAPMAN, P. M. 2016. Ecological risk and weight of evidence assessments. In: BLASCO, J., CHAPMAN, P. M., CAMPANA, O. \& HAMPEL, M. (eds.). Marine Ecotoxicology: Current Knowledge and Future Issues. San Diego, USA: Academic Press - Elsevier Inc.

CICIN-SAIN, B. \& BELFIORE, S. 2005. Linking marine protected areas to integrated coastal and ocean management: a review of theory and practice. Ocean \& Coastal Management, 48(11-12), 847-868.

CONTI, L. A., ARAUJO, C. A., PAOLO, F. S., BARCELLOS, R. L., RODRIGUES, M., MAHIQUES, M. M. \& FURTADO, V. V 2012. An integrated GIS for sedimentological and geomorphological analysis of a lagoon environment. Barra de Cananeia inlet region, (Southeastern Brazil). Journal of Coastal Conservation, 16(1), 13-24. 
COPPUS, R. \& IMESON, A. C. 2002. Extreme events controlling erosion and sediment transport in a semi-arid sub-andean valley. Earth Surface Processes and Landforms, 27(13), 13651375.

CORSI, A. C. \& LANDIM, P. M. B. 2002. Fluvial transport of lead, zinc and copper contents in polluted mining regions. Environmental Geology, 41(7), 833-841.

CORSI, A. C. \& LANDIM, P. M. B. 2003. Chumbo, Zinco e Cobre em sedimentos de corrente nos Ribeirões Grande, Perau e Canoas, e Córrego Barrinha no município de Adrianopólis Vale do Ribeira. Geociências, 22, 49-61.

COSTA NETO, J. B., MARETTI, C. C., LINO, C. F. \& ALBUQUERQUE, J. L. R. 1997. A reserva da biosfera da Mata Atlântica no Estado de São Paulo. São Paulo, Brazil: CETESB/Instituto Florestal. Available at: http://www.rbma.org.br/rbma/pdf/Caderno_05.pdf [Accessed 23 September. 2019].

COSTA, F. H. S., SOUZA FILHO, C. R. \& RISSO, A. 2009. Modelagem espaço-temporal da erosão e potencial contaminação de Arsênio e Chumbo na bacia hidrográfica do rio Ribeira de Iguape (SP). Revista Brasileira de Geociências, 39(2), 338-349.

CRUZ, A. C. F., DAVANSO, M. B., ARAUJO, G. S., BURUAEM, L. M., SANTAELLA, S. T., MORAIS, R. D. \& ABESSA, D. M. S. 2014. Cumulative influences of a small city and former mining activities on the sediment quality of a subtropical estuarine protected area. Environmental Monitoring and Assessment, 186(11), 7035-7046.

CRUZ, A. C. F., GUSSO-CHOUERI, P., ARAUJO, G. S., CAMPOS, B. G. \& ABESSA, D. M. S. 2019. Levels of metals and toxicity in sediments from a Ramsar site influenced by former mining activities. Ecotoxicology and Environmental Safety, 171, 162172.

CUNHA, D. G. F., CALIJURI, M. D. C. \& MIWA, A. C. P. 2007. A precipitação pluviométrica como agente indutor de modificações nas características químicas do sedimento do rio Jacupiranguinha, Vale do Ribeira de Iguape, SP. Minerva, 4, 41-49.

CUNHA, F. G., FIGUEIREDO, B. R., PAOLIELLO, M. M. B., CAPITANI, E. M. \& SAKUMA, A. M. 2005. Human and environmental lead contamination in the Upper Ribeira Valley, southeastern Brazil. Terrae, 2(1-2), 28-36.

CUNHA-LIGNON, M., KAMPEL, M., MENGHINI, R. P., NOVELLI, Y. S., CINTRÓN, G. \& GUEBAS, F. D. 2011. Mangrove forests submitted to depositional processes and salinity variation investigated using satellite images and vegetation structure surveys. Journal of Coastal Research, 64spe, 344-348.

CUNHA-LIGNON, M., MAHIQUES, M. M., SCHAEFFER-NOVELLI, Y., RODRIGUES, M., KLEIN, D. A., GOYA, S. C., MENGHINI, R. P., TOLENTINO, C. C., CINTRÓN-MOLERO, G., HDOUH-GUEBAS, F., MEHGHINI, R. P., TOLENTINO, C. C., CINTRON-MOLERO, G. \& DAHDOUH-GUEBAS, F. 2009. Analysis of mangrove forest succession, using sediment cores: a case study in the Cananeia-Iguape coastal system, Sao Paulo-Brazil. Brazilian Journal of Oceanography, 57, 161-174.

CURCHO, M. R. S. M., FARIAS, L. A., BAGGIO, S. R., FONSECA, B. C., NASCIMENTO, S. M., BORTOLI, M. C., BRAGA, E. D. S. \& FÁVARO, D. I. T. 2009. Mercury and methylmercury content, fatty acids profile, and proximate composition of consumed fish in Cananéia, São Paulo, Brazil. Revista do Instituto Adolfo Lutz, 68(3), 442-450.
DAEE (Departamento de Águas e Energia Elétrica do Estado de São Paulo). 1998. Bacia hidrográfica do Ribeira de Iguape: relatório síntese do plano de ação. São Paulo, Brasil: DAAE. Available at: http://www.daee.sp.gov.br/acervoepesquisa/ relatorios/revista/raee9904/ribeira_do_iguape.htm [Accessed 29 November. 2019].

DAEE (Departamento de Águas e Energia Elétrica do Estado de São Paulo). 2019. Banco de dados fluviométricos do Estado de São Paulo. Banco de dados hidrológicos. São Paulo, Brasil: DAAE. Available at: https://www.hidrologia.daee.sp.gov.br/ [Accessed 29 November. 2019].

DAY, J., DUDLEY, N., HOCKINGS, M., HOLMES, G., LAFFOLEY, D., STOLTON, S. \& WELLS, S. 2012. Guidelines for applying the IUCN protected area management categories to marine protected areas. Gland, Switzerland: IUCN.

DEPLEDGE, M. H. 1993. The rational basis for the use of biomarkers as ecotoxicological tools. In: FOSSI, M. C. \& LEONZIO, C. (eds.). Nondestructive biomarkers in vertebrates. Boca Raton, USA: Lewis Publishers.

DEVI, M. \& FINGERMAN, M. 1995. Inhibition of acetylcholinesterase activity in the central nervous system of the red swamp crayfish, Procambarus clarkii, by mercury, cadmium, and lead. Bulletin of Environmental Contamination and Toxicology, 55, 746-750.

DU LAING, G., RINKLEBE, J., VANDECASTEELE, B., MEERS, E. \& TACK, F. M. 2009. Trace metal behaviour in estuarine and riverine floodplain soils and sediments: a review. Science of The Total Environment, 407(13), 3972-3985.

EBRAHIMPOUR, M. \& MUSHRIFAH, I. 2008. Heavy metal concentrations ( $\mathrm{Cd}, \mathrm{Cu}$ and $\mathrm{Pb})$ in five aquatic plant species in Tasik Chini, Malaysia. Environmental Geology, 54(4), 689-698.

EC (Commission of the European Communities). 2006. COMMISSION REGULATION (EC) No 1881/2006 of 19 December 2006 setting maximum levels for certain contaminants in foods tuffs, vol. L 364/5. European Union: EC.

ELLIOTT, M. \& MCLUSKY, D. S. 2002. The need for definitions in understanding estuaries. Estuarine, Coastal and Shelf Science, 55(6), 815-827.

EYSINK, G. G. J., BOLDRINI, C. V., FOMASSARO, G. J., LUCA, K., RAMOS, M. L. L., CARVALHO, M., HUMYTA, M. E. P., IMENEZ, L. P., LAMPARELLI, M. C. \& ARAÚJO, R. P. A. 1991. Avaliação da qualidade ambiental do rio Ribeira de Iguape: considerações preliminares. São Paulo, Brazil: CETESB.

EYSINK, G. G. J., PADUA, H. B. \& PIVA-BERTOLETTI, S. A. E. 1987. Considerações preliminares sobre o nível de contaminação por metais pesados e pesticidas organoclorados no complexo Estuarino-Lagunar Iguape Cananéia e Vale do Ribeira, Simpósio sobre Ecossistemas da Costa Sul e Sudeste Brasileira, vol. 3, pp. 258-266. Cananéia, Brazil: ACIESP.

EYSINK, G. G. J., PADUA, H. B., PIVA-BERTOLETTI, S. A. E., MARTINS, M. C. \& PEREIRA, D. N. 1988. Metais pesados no Vale do Ribeira e em Iguape-Cananéia. Ambiente, 2(1), 6-13.

FAO/WHO (Food and Agriculture Organization/World Health Organization). 2004. Limit test for heavy metals in food additive specifications - Explanatory note. Geneva, Switzerland: JOINT FAO/ WHO EXPERT COMMITTEE ON FOOD ADDITIVES (JECFA). Available at: http://www.fao.org/food/food-safety-quality/scientificadvice/jecfa/guidelines0/en/ [Accessed 15 February. 2020]. 
FERNANDEZ, W. S., DIAS, J. F., BOUFLEUR, L. A., AMARAL, L. \& YONEAMA, M. L. 2014. Bioacumulation of trace elements in hepatic and renal tissues of the white mullet Mugil curema Valenciennes, 1836 (Actinopterygii, Mugilidae) in two coastal systems in southeastern Brazil. Nuclear Instruments and Methods in Physics Research, Section B: Beam Interactions with Materials and Atoms, 318(Pt A), 94-98.

FITZGERALD, W. F., ENGSTROM, D. R., MASON, R. P. \& NATER, E. A. 1998. The case for atmospheric mercury contamination in remote areas. Environmental Science \& Technology, 32(1), 1-7.

FONTES, R. F. C., FEY, J. D., OLIVEIRA, A. J. F. C. \& BARBIERI, E. 2019. Numerical modeling as supporting tool for aquaculture of oysters in a subtropical estuarine ecosystem. Boletim do Instituto de Pesca, 45(4), e487.

FRANCHI, J. G. 2004. A utilização de turfa como adsorvente de metais pesados: $O$ exemplo da contaminação da Bacia do Rio Ribeira de lguape por chumbo e metais associados. PhD. São Paulo University. Available at: http://www.teses.usp.br/ teses/disponiveis/44/44134/tde-01122004-122248/en.php [Accessed 31 August. 2019].

GALVÃO, M. S. N., PEREIRA, O. M., MACHADO, I. C. \& HENRIQUES, M. B. 2000. Aspectos reprodutivos da ostra Crassostrea brasiliana (Lamarck, 1819) em manguezal do estuário de Cananéia, SP (025oS; 048oW). Boletim do Instituto da Pesca, $26,147-162$.

GARTEN, C. T. \& ASHWOOD, T. L. 2004. Modeling soil quality thresholds to ecosystem recovery at Fort Benning, GA, USA. Ecological Engineering, 23, 351-369.

GUIMARÃES, V. \& SíGOLO, J. B. 2008a. Association of metallurgical residues in suspended sediments in the Ribeira de Iguape River. [Associação de Resíduos da Metalurgia com Sedimentos em Suspensão] - Rio Ribeira de Iguape. Geologia USP. Série Científica, 8(2), 1-8.

GUIMARÃES, V. \& SÍGOLO, J. B. 2008b. Dectection of contaminants in a bioindicator species (Corbicula fluminea) - Ribeira de Iguape River, São Paulo State. Química Nova, 31(7), 1696-1698.

GUSSO-CHOUERI, P. K., ARAÚJO, G. S., CRUZ, A. C. F., STREMEL, T. R. O., CAMPOS, S. X., ABESSA, D. M. S., RIBEIRO, C. A. O. \& CHOUERI, R. B. 2018. Metals and arsenic in fish from a Ramsar site under past and present human pressures: Consumption risk factors to the local population. Science of the Total Environment, 628-629, 621-630.

GUSSO-CHOUERI, P. K., BRASIL, R., SANTOS, G. S., ARAÚJO, G. S., CRUZ, A. C. F., STREMEL, T., CAMPOS, S. X., CESTARI, M. M., RIBEIRO, C. A. O. \& ABESSA, D. M. S. 2016. Assessing genotoxic effects in fish from a marine protected area in fluenced by former mining activities and other stressors. Marine Pollution Bulletin, 104, 229-239.

GUSSO-CHOUERI, P. K., CHOUERI, R. B., ARAÚJO, G. S., CRUZ, A. C. F., STREMEL, T., CAMPOS, S., ABESSA, D. M. S. \& RIBEIRO, C. A. O. 2015. Assessing pollution in marine protected areas: the role of a multi-biomarker and multi-organ approach. Environmental Science and Pollution Research, 22, 18047-18065.

HANAZAKI, N., CASTRO, F., OLIVEIRA, V. G. \& PERONI, N. 2007. Between the sea and the land : the livelihood of estuarine people in southeastern Brazil. Ambiente \& Sociedade, X(1), 121-136.

HENRIQUES, M. B., MACHADO, I. C. \& FAGUNDES, L. 2010. Análise econômica comparativa dos sistemas de cultivo integral e de 'engorda' da ostra do mangue Crassostrea spp. no estuário de Cananéia, São Paulo, Basil. Boletim do Instituto de Pesca, 36(4), 307-316.
HORVAT, M. 1996. Mercury analysis and speciation in environmental samples. In: BAEYENS, W., EBINGHAUS, R. \& VASILIEV, O. (eds.). Global and Regional Mercury Cycles: Sources, Fluxes and Mass Balances, Nato Science Partnership Subseries: 2. Environment Security. Dordrecht: Springer Netherlands.

IBAMA/SMA-SP (Instituto Brasileiro do Meio Ambiente e dos Recursos Naturais Renováveis; Secretaria do Meio Ambiente do Estado de São Paulo). 1996. Regulamentação da APA Cananéia Iguape Peruíbe: Plano de Gestão:Unidades de Gestão-ZEE Preliminar. Convênio IBAMA/SMA 033/95. São Paulo: IBAMA/SMA-SP.

JAMESON, S. C., TUPPER, M. H. \& RIDLEY, J. M. 2002. The three screen doors: can marine "protected" areas be effective? Marine Pollution Bulletin, 44(11), 1177-1183.

JICKELLS, T. D. \& RAE, J. E. 1997. Biogeochemistry of intertidal sediments. New York, USA: Cambridge University Press.

JOHNSON, V. G., PETERSON, R. E. \& OLSEN, K. B. 2005. Heavy metal transport and behavior in the lower Columbia River, USA. Environmental monitoring and assessment, 110, 271-89.

JONASSON, C. \& NYBERG, R. 1999. The Rainstorm of August 1998 in the Abisko Area, Northern Sweden: preliminary report on observations of erosion and sediment transport. Geografiska Annaler, Series A: Physical Geography, 81(Pt A), 387-390.

KELLEHER, G. 1999. Guidelines for marine protected areas. Gland, Switzerland and Cambridge, UK: IUCN.

KELLEHER, G., BLEAKLEY, C. \& WELLS, S. 1995. A global representative system of marine protected areas. A joint publication of the World Bank, The Great Barrier Reef Marine Park Authority and the World conservation Union (IUCN). Washington, USA: IUCN.

KIRSCHBAUM, A. A., SERIANI, R., PEREIRA, C. D. S., ASSUNÇÃO, A., ABESSA, D. M. S., ROTUNDO, M. M. \& RANZANI-PAIVA, M. J. T. 2009. Cytogenotoxicity biomarkers in fat snook Centropomus parallelus from Cananéia and São Vicente estuaries, SP, Brazil. Genetics and Molecular Biology, 32(1), 151-154.

KUMMER, L., MELO, V. F., BARROS, Y. J. \& AZEVEDO, J. C. R. 2011. Sequential extraction of lead and zinc from soils of heavy metal mining and processing area. Revista Brasileira de Ciência do Solo, 35(6), 2005-2018.

KUTNER, M. B. B. \& AIDAR-ARAGAO, E. 1986. Influencia do fechamento do Valo Grande sobre a composição do fitoplancton na região de Cananéia (25'S-48'W). In: BICUDO, E., TEIXEIRA, C. \& TUNDISI, J. G. (eds.). Algas: a energia do amanhã. São Paulo, Brazil: Instituto Oceanográfico - Universidade de São Paulo.

LACERDA, L. D., GUIMARAES, J. R. D. \& TEIXEIRA, V. L. 1985. Seasonal variation of heavy metals in seaweeds from Conceição de Jacarei (R.J.), Brazil. Botanica Marina, 28(8), 339-344.

LACERDA, L. D. \& MOLISANI, M. M. 2006. Three decades of Cd and Zn contamination in Sepetiba Bay, SE Brazil: evidence from the mangrove oyster Crassostraea rhizophorae. Marine Pollution Bulletin, 52(8), 969-987.

LAMPARELLI, M. C., COSTA, M. P., PRÓSPERI, V. A., BEVILACQUA, J. E., ARAÚJO, R. P., EYSINC, G. G. J. \& POMPÉIA, S. 2001. Sistema estuarino de Santos e São Vicente - "Levantamento da contaminação ambiental do sistema estuarino de Santos e São Vicente". São Paulo, Brazil: PROCOP - Programa de Controle de Poluição.

LAUSCHE, B. 2011. Guidelines for protected areas legislation. Gland, Switzerland: IUCN. 
LEWIS, M., PRYOR, R. \& WILKING, L. 2011. Fate and effects of anthropogenic chemicals in mangrove ecosystems: a review. Environmental Pollution, 159(10), 2328-2346.

LI, Z., MA, Z., KUIJP, T. J. V. D., YUAN, Z. \& HUANG, L. 2014. A review of soil heavy metal pollution from mines in China: Pollution and health risk assessment. Science of the Total Environment, 468-469, 843-853.

LINO, C. F., DIAS, H. \& ALBUQUERQUE, J. L. 2011. The Mata Atlântica Biosphere Reserve: review and uptade of the limits and the zoning of the Mata Atlântica Biosphere Reserve in digital carthographic base: phase V (No. 40). Brazil: Programa de Cooperación Sur-Sur/UNESCO. Available at: http://unesdoc. unesco.org/images/0021/002114/211414m.pdf [Accessed 23 September. 2019].

LOPES JUNIOR, I. 2007. Atlas Geoquímico do Vale do Ribeira: geoquímica dos sedimentos ativos de corrente, 2nd ed. São Paulo, Brasil: Serviço Geológico do Brasil (CPRM). Available at: http://www.cprm.gov.br/publique/media/atlas_geoq_ apre.pdf [Accessed 24 August. 2019].

MACÊDO, G. R., TARANTINO, T. B., BARBOSA, I. S., PIRES, T.T., ROSTAN, G., GOLDBERG, D. W., PINTO, L. F. B., KORN, M. G. A. \& FRANKE, C. R. 2015. Trace elements distribution in hawksbill turtle (Eretmochelys imbricata) and green turtle (Chelonia mydas) tissues on the northern coast of Bahia, Brazil. Marine Pollution Bulletin, 94(1-2), 284-289.

MACHADO, I. C., MAIO, F. D., KIRA, C. S. \& CARVALHO, M. F. H. 2002. $\mathrm{Pb}, \mathrm{Cd}, \mathrm{Hg}, \mathrm{Cu}$ and $\mathrm{Zn}$ in mangrove oyster Crassostrea brasiliana Cananéia estuary, São Paulo - Brazil. Revista do Instituto Adolfo Lutz, 61(1), 13-18.

MACHADO, I. C., FAGUNDES, L. \& HENRIQUES, M. B. 2010. Perfil socioeconômico e produtivo dos extrativistas da ostra de mangue Crassostrea spp. em Cananéia, São Paulo, Brasil. Informações Econômicas, 40(7), 67-79.

MACHADO, I., FAGUNDES, L. \& HENRIQUES, M. 2015. Multidimensional assessment of sustainability extractivism of mangrove oyster Crassostrea spp. in the estuary of Cananéia, São Paulo, Brazil. Brazilian Journal of Biology, 75(3), 670-678.

MAHIQUES, M. M., BURONE, L., FIGUEIRA, R. C. L., LAVENÉRE-WANDERLEY, A. A. D. O., CAPELLARI, B., ROGACHESKI, C. E., BARROSO, C. P., SANTOS, L. A. S., CORDERO, L. M. \& CUSSIOLI, M. C. 2009. Anthropogenic influences in a lagoonal environment: a multiproxy approach at the valo grande mouth, Cananéia-Iguape system (SE Brazil). Brazilian Journal of Oceanography, 57, 325-337.

MAHIQUES, M. M., FIGUEIRA, R. C. L., SALAROLI, A. B., ALVES, D. P. V. \& GONÇALVES, C. 2013. 150 years of anthropogenic metal input in a biosphere reserve: the case study of the Cananéia-Iguape coastal system, Southeastern Brazil. Environmental Earth Sciences, 68(4), 1073-1087.

MARTINEZ, S., MAHIQUES, M. M. \& BURONE, L. 2013. Mollusks as indicators of historical changes in an estuarine-lagoonal system (Cananeia-lguape, SE Brazil). The Holocene, 23(6), 888-897.

MASSON, M., BLANC, G. \& SCHÄFER, J. 2006. Geochemical signals and source contributions to heavy metal $(\mathrm{Cd}, \mathrm{Zn}, \mathrm{Pb}$, $\mathrm{Cu}$ ) fluxes into the Gironde Estuary via its major tributaries. The Science of the total environment, 370(1), 133-46.

MCLUSKY, D. S. \& ELLIOTT, M. 2004. The estuarine ecosystem: ecology, threats, and management, 3rd ed. New York, USA: Oxford University Press.
MELO, V. F., ANDRADE, M., BATISTA, A. H., FAVARETTO, N., GRASSI, M. T. \& CAMPOS, M. S. 2012. Lead and zinc in water and sediments of a metal mining and metallurgy area. Química Nova, 35(1), 22-29.

MENDONÇA, J. T. \& KATSURAGAWA, M. 2001. Caracterização da pesca artesanal no complexo estuarino-lagunar de Cananéia-Iguape, Estado de São Paulo, Brasil (1995-1996). Acta Scientiarum, 23(2), 535-547.

MENDONÇA, J.T. \& MIRANDA, L. V. 2008. Estatística pesqueira do litoral sul do estado de São Paulo: subsídios para gestão compartilhada. Pan-American Journal of Aquatic Sciences, 3(3), 152-173.

MENDONÇA, J. T. \& MACHADO, I. C. 2010. Mangrove oyster (Crassostrea spp.) (Sacco, 1897) extractivism in Cananéia estuary (São Paulo, Brazil) from 1999 to 2006: capture and management evaluation. Brazilian Journal of Biology, 70(1), 65-73.

MERCOSUL (Mercado Comum do Sul). 2011. Regulamento técnico mercosul sobre limites máximos de contaminantes inorgânicos em alimentos. GMC N ${ }^{\circ} 12 / 2011$. 18. Montevidéu, Uruguai: MERCOSUL. Available at: https://gestorweb.mercosur. int [Accessed 15 February. 2020].

MIRANDA, L. B., CASTRO, B. M. \& KJERFVE, B. 2002. Princípios em Oceanografia Física de Estuários. São Paulo, Brazil: Editora da Universidade de São Paulo.

MIRANDA, L. B., MESQUITA, A. R. \& FRANÇA, C. A. S. 1995. Estudo da circulação e dos processos de mistura no extremo sul do mar de Cananéia: condições de dezembro de 1991. Boletim do Instituto Oceanográfico, 43(2), 153-164.

MISHIMA, M., YAMANAKA, N., JACOBSEN, O., PEREIRA, O. M., SOARES, F. C., SINQUE, C. \& AKABOSHI, S. 1986. Hidrografia do complexo Estuarino Lagunar de Cananéia ( $25^{\circ} \mathrm{S}$ e $48^{\circ} \mathrm{W}$ ), São Paulo, Brasil. Boletim do Instituto de Pesca, 13, 51-70.

MIYAO, S. Y. \& HARARI, J. 1989. Estudo preliminar da maré e das correntes de maré da região estuarina de Cananéia $\left(25^{\circ} \mathrm{S}-\right.$ $48^{\circ} \mathrm{W}$ ). Boletim do Instituto Oceanográfico, 37(2), 107-123.

MIYAO, S. Y., NISHIHARA, L. \& SARTI, C. C. 1986. Características físicas e químicas do sistema estuarino-lagunar de Cananéia-Iguape. Boletim do Instituto Oceanográfico, 34, 23-36.

MOL, J. H., RAMLAL, J. S., LIETAR, C. \& VERLOO, M. 2001. Mercury contamination in freshwater, estuarine, and marine fishes in relation to small-scale gold mining in Suriname, South America. Environmental Research, 86(2), 183-97.

MONTEIRO-NETO, C., ITAVO, R. V. \& MORAES, L. E. 2003. Concentrations of heavy metals in Sotalia fluviatilis (Cetacea: Delphinidae) off the coast of Ceará, northeast Brazil. Environmental Pollution, 123(2), 319-24.

MOORE, J. N., BROOK, E. J. \& JOHNS, C. 1989. Grain size partitioning of metals in contaminated, coarse-grained river floodplain sediment: Clark Fork River, Montana, U.S.A. Environmental Geology and Water Sciences, 14(2), 107-115.

MORAES, M. B. R. 2004. Área de Proteção Ambiental APA como agência de desenvolvimento sustentável: APA Cananéia Iguape Peruíbe/SP. São Paulo, Brazil: Annablume/FAPESP.

MORAES, R. P., FIGUEIREDO, B. R. \& LAFON, J. 2004. Pb-Isotopic tracing of metal-pollution sources in the Ribeira Valley, Southeastern Brazil. Terrae, 1(1), 26-33.

MORAIS, L. G. \& ABESSA, D. M. S. 2014. PSR framework applied to the coastal management of "Complexo Estuarino-Lagunar Iguape-Cananéia" - CELIC (São Paulo, Brazil), in terms of sanitation and public health. Journal of Integrated Coastal Zone Management, 14(4), 625-635. 
MORAIS, L. G., PERINA, F. C., DAVANSO, M. B., MOREIRA, L. B., RODRIGUES, V. G. S., SÍGOLO, J. B. \& ABESSA, D. M. S. 2013. Water and sediment ecotoxicological assessment in a river affected by former mining activities. Pan-American Journal of Aquatic Sciences, 8(4), 327-338.

MORGAN, R. P. C., QUINTON, J. N., SMITH, R. E., GOVERS, G., POESEN, J. W. A., AUERSWALD, K., CHISCl, G., TORRI, D. \& STYCZEN, M. E. 1998. The European soil erosion model (EUROSEM): a dynamic approach for predicting sediment transport from fields and small catchments. Earth Surface Processes and Landforms, 23, 527-544.

MORGENTAL, A., BATOLLA JR, F., PINTO, G. G., PAIVA, I. P. \& DRUMOND, J. B. V. 1975. Projeto Sudelpa: relatório final - geologia, vol. 1/18 v. São Paulo, Brazil: CPRM. Available at: http:// rigeo.cprm.gov.br/xmlui/handle/doc/6769 [Accessed 24 August. 2019].

MORGENTAL, A., BORIN JUNIOR, T., SILVA, A. A. G. P., ALEGRI, V., OLIVEIRA, P. E. P., MACHADO, G. J. \& ADDAS, W. 1978. Projeto Geoquímica no Vale do Ribeira, vol. 1/8v. São Paulo, Brazil: CPRM. Available at: http://rigeo.cprm.gov.br/xmlui/handle/ doc/9503 [Accessed 24 August. 2019].

NAGELKERKEN, I., BLABER, S. J. M., BOUILLON, S., GREEN, P., HAYWOOD, M., KIRTON, L. G., MEYNECKE, J. O., PAWLIK, J., PENROSE, H. M., SASEKUMAR, A. \& SOMERFIELD, P. J. 2008. The habitat function of mangroves for terrestrial and marine fauna: a review. Aquatic Botany, 89(2), 155-185.

ONOFRE, C. R. E., CELINO, J. J., MARIA, R., NANO, W., FERNANDO, A. \& QUEIROZ, D. S. 2007. Metal bioavailability in mangrove sediments from north portion to the Todos os Santos Bay, Bahia, Brazil. Revista de Biologia e Ciências da Terra, 7(2), 6582.

OSHER, L. J., LECLERC, L., WIERSMA, G. B., HESS, C.T. \& GUISEPPE, V.E. 2006. Heavy metal contamination from historic mining in upland soil and estuarine sediments of Egypt Bay, Maine, USA. Estuarine, Coastal and Shelf Science, 70(1-2), 169-179.

PEREIRA, M. O., CALZA, C., LOPES, R. T. \& ANJOS, M. J. 2006. Metal concentrations in surface sediments of Paraiba do Sul River (Brazil). Journal of Radioanalytical and Nuclear Chemistry, 269(3), 707-709.

PEREIRA, O. M., MACHADO, I. C., HENRIQUES, M. B. \& YAMANAKA, N. 2001. Crescimento da ostra Crassostrea brasiliana semeada sobre tabuleiro em diferentes densidades na região Estuarino-Lagunar de Cananéia-SP (25o S, 480 W). Boletim do Instituto de Pesca, 27(2), 163-174.

PERONI, N., BEGOSSI, A. \& HANAZAKI, N. 2008. Artisanal fishers' ethnobotany: from plant diversity use to agrobiodiversity management. Environment, Development and Sustainability, 10(5), 623-637.

PIVA-BERTOLETTI, S. A. \& PADUA, H. B. 1986. Avaliacao dos niveis de contaminacao por metais e pesticidas organoclorados na agua, ictiofauna e outros organismos aquaticos do complexo estuarino-lagunar Iguape-Cananeia. São Paulo, Brasil: Companhia de Tecnologia de Sanemanto Ambiental.

POSTMA, H. 1967. Sediment transport and sedimentation in the estuarine environment. In: LAUFF, G. H. (ed.). Estuaries. Washington, USA: American Association for Advancement of Science.

POWER, E. A. \& CHAPMAN, P. M. 1992. Assessing sediment quality. In: BURTON, J. A. G. (ed.). Sediment toxicity assessment. Boca Raton, USA: Lewis Publisher.
PRICE, G. D., WINKLE, K. \& GEHRELS, W. R. 2005. A geochemical record of the mining history of the Erme Estuary, south Devon, UK. Marine Pollution Bulletin, 50(12), 1706-17012.

PUEYO, M., RAURET, G., LÜCK, D., YLI-HALLA, M., MUNTAU, H., QUEVAUVILLER, P. \& LÓPEZ-SÁNCHEZ, J. F. 2001. Certification of the extractable contents of $\mathrm{Cd}, \mathrm{Cr}, \mathrm{Cu}, \mathrm{Ni}, \mathrm{Pb}$ and $\mathrm{Zn}$ in a freshwater sediment following a collaboratively tested and optimised three-step sequential extraction procedure. Journal of Environmental Monitoring, 3(2), 243-50.

RAE, J. E. 1997. Trace metals in deposited intertidal sediments. In: JICKELLS, T. D. \& RAE, J. E. (eds.). Biogeochemistry of intertidal sediments. Cambridge, UK: Cambridge University Press.

RAMSAR CONVENTION SECRETARIAT. 2016. An introduction to the Ramsar Convention on Wetlands, Ramsar Handbooks 5th ed. Sub-series I: Handbook. International Cooperation on Wetlands. Gland, Switzerland: RAMSAR.

REBELO, M. F., AMARAL, M. C. R. \& PFEIFFER, W. C. 2003. High Zn and $\mathrm{Cd}$ accumulation in the oyster Crassostrea rhizophorae, and its relevance as a sentinel species. Marine Pollution Bulletin, 46, 1354-1358.

RIBA, I., BLASCO, J., JIMÉNEZ-TENORIO, N., CANALES, M. L. G. \& DELVALLS, T. A. 2005. Heavy metal bioavailability and effects: II. Histopathology-bioaccumulation relationships caused by mining activities in the Gulf of Cádiz (SW, Spain). Chemosphere, 58, 671-682.

RODRIGUES, S. K., ABESSA, D. M. S. \& MACHADO, E. C. 2013. Geochemical and ecotoxicological assessment for estuarine surface sediments from Southern Brazil. Marine Environmental Research, 91, 68-79.

RODRIGUES, V. G. S., FUJIKAWA, A., ABESSA, D. M. S., HORTELLANI, M. A., SARKIS, J. E. S. \& SíGOLO, J. B. 2012. Uso do bivalve límnico Anodontites tenebricosus (LEA, 1834) no biomonitoramento de metais do Rio Ribeira de Iguape. Química Nova, 35, 454-459.

RSIS (Ramsar Sites Information Service). 2017. Ramsar information sheet for site no. 2310, Environmental protection area of Cananéia-lguape-Peruíbe. Brazil: RSIS. Available at: https://rsis.ramsar.org/ris/2310 [Accessed Dia Mês. Ano].

SAITO, R. T., FIGUEIRA, R. C. L., TESSLER, M. G. \& CUNHA, I. I. L. 2001a. $\mathrm{Pb}-210$ and $\mathrm{Cs}-137$ geochronologies in the Cananeia-Iguape Estuary (Sao Paulo, Brazil). Journal of Radioanalytical and Nuclear Chemistry, 249(1), 257-261.

SAITO, R. T., FIGUEIRA, R. C. L., TESSLER, M. G. \& CUNHA, I. I. L. 2001b. Geochronology of sediments in the Cananeia-Iguape estuary and in southern continental shelf of Sao Paulo State, Brazil. Journal of Radioanalytical and Nuclear Chemistry, 250, 109-115.

SALGADO, L. D. 2015. Avaliação da biodisponibilidade e a bioacumulação de metais em botos-cinza do Complexo Estuarino-Lagunar de lguape-Cananéia, SP. M.e. Universidade Tecnológica Federal do Paraná. Available at: http://repositorio.utfpr.edu.br:8080/ jspui/bitstream/1/1192/1/CT_PPGCTA_M_Salgado\%2c\%20Lilian\%20Dalago_2015.pdf [Accessed Dia Mês. Ano].

SALM, R. V., CLARK, J. R. \& SIIRILA, E. 2000. Marine and coastal protected areas: a guide for planners and managers, 3rd ed. Washington, USA: IUCN.

SANTOS, K. M. P. \& TATTO, N. 2008. Agenda socioambiental de comunidades quilombolas do Vale do Ribeira. São Paulo, Brazil: Instituto Socioambiental (ISA). Available at: https:// www.socioambiental.org/pt-br/o-isa/publicacoes/agenda-socioambiental-de-comunidades-quilombolas-do-vale-do-ribeira [Accessed Dia Mês. Ano]. 
SCHAEFFER-NOVELLI, Y., MESQUITA, H. S. L. \& CINTRÓN-MOLERO, G. 1990. The Cananéia Lagoon Estuarine System, São Paulo, Brazil. Estuaries, 13(2), 193-203.

SENEZ-MELLO, T. M., CRAPEZ, M. A. C., RAMOS E SILVA, C. A., SILVA, E. T. \& FONSECA, E. M. 2020. Heavy metals bioconcentration in Crassostrea rhizophorae: a site-to-site transplant experiment at the Potengi estuary, Rio Grande do Norte, Brazil. Scientific Reports, 10, 246.

SIG-RB (Sistema de Informações Geográficas da Bacia do Ribeira de Iguape e Litoral Sul). 2012. Relatório de Situação dos Recursos Hídricos da UGRHI 11 - Bacia Hidrográfica do Ribeira de Iguape e Litoral Sul - Ano-Base 2011. Registro, Brazil: SIG-RB. Available at: http://www.sigrb.com.br [Accessed 29 November. 2019].

SILVA, I. F. 1989. Dados climatológicos de Cananéia e Ubatuba (Estado de São Paulo). Série de 1956-1985. Boletim Climatológico do Instituto Oceanográico, 6, 1-21.

SSE/SP (Secretaria de Saneamento e Energia do Estado de São Paulo) 2010. Ribeira do Iguape e Litoral Sul: Plano Regional Integrado de Saneamento Básico para a UGRHI - 11. Programa de Fortalecimento dos Instrumentos de Planejamento do Setor de Saneamento. São Paulo, Brazil: SSE/SP. Available at: http://www. saneamento.sp.gov.br [Accessed 29 November. 2019].

SILVA, C. A. R., RAINBOW, P. S. \& SMITH, B. D. 2003. Biomonitoring of trace metal contamination in mangrove-lined Brazilian coastal systems using the oyster Crassostrea rhizophorae: comparative study of regions affected by oil, salt pond and shrimp farming activities. Hydrobiologia, 501(1), 199-206.

SILVA, C. C., VARELA JUNIOR, A. S., BARCAROLLI, I. F. B. \& BIANCHINI, A. 2014. Concentrations and distributions of metals in tissues of stranded green sea turtles (Chelonia mydas) from the southern Atlantic coast of Brazil. Science of the Total Environment, 466-467, 109-118.

SIMPSON, S. L., CAMPANA, O. \& HO, K. T. 2016. Sediment toxicity testing. In: BLASCO, J., CHAPMAN, P. M., CAMPANA, O. \& HAMPEL, M. (eds.). Marine ecotoxicology: current knowledge and future issues. San Diego, USA: Academic Press - Elsevier Inc.

SUGUIO, K. \& MARTIN, L. 1978. Quaternary marine formation of the states of São Paulo and Southern Rio de Janeiro International Symposium on Coastal Evolution in the Quaternary, vol. 1 spe. São Paulo, Brazil: Brasilian National Working Group for the IGCP-Project 61.

SUGUIO, K., MARTIN, L. \& FLEXOR, J. M. 1988. Quaternary sea levels of the Brazilian coast: recent progress. Episodes, 11(3), 203-208.

SWEET, L. I. \& ZELIKOFF, J. T. 2001. Toxicology and immunotoxicology of mercury: a comparative review in fish and humans. Journal of Toxicology and Environmental Health, Part B: Critical Reviews, 4(2), 161-205.

TERLIZZI, A., DELOS, A. L., GARAVENTA, F., FAIMALI, M. \& GERACI, S. 2004. Limited effectiveness of marine protected areas: imposex in Hexaplex trunculus (Gastropoda, Muricidae) populations from Italian marine reserves. Marine Pollution Bulletin, 48, 188-192.

TESSLER, G. M., SUGUIO, K. \& ROBILOTA, P. R. 1987. Teores de alguns elementos traços metálicos em sedimentos pelíticos da superfície de fundo da região lagunar Cananéia-lguape (SP) Simpósio sobre Ecossistemas da Costa Sul e Sudeste Brasileira, vol. 2, pp. 255-263. Cananéia, Brazil: ACIESP.
TESSLER, M. G. \& FURTADO, V. V. 1983. Dynamics of sediments in deposition in the lagunar region of Cananéia-lguape, State of São Paulo. Boletim do Instituto Oceanográfico, 32, 117-124.

TESSLER, M. G. \& SOUZA, L. A. P. 1998. Dinâmica sedimentar e feições sedimentares identificadas na superfície de fundo do sistema Cananéia-Iguape, SP. Revista Brasileira de Oceanografia, 46(1), 69-83.

THEODOROVICZ, A. \& THEODOROVICZ, A. M. D. G. 2007. Atlas geoambiental: subsídios ao planejamento territorial e à gestão ambiental da bacia hidrográfica do rio Ribeira de Iguape. São Paulo, Brasil: Serviço Geoloógico do Brasil (CPRM). Available at: http://www.cprm.gov.br/publique/media/atlas_geoambiental.pdf [Accessed 24 August. 2019].

TRAMONTE, K. M., FIGUEIRA, R. C. L., MAJER, A. P., FERREIRA, P. A. L., BATISTA, M. F., RIBEIRO, A. P. \& MAHIQUES, M. M. 2018. Geochemical behavior, environmental availability, and reconstruction of historical trends of $\mathrm{Cu}, \mathrm{Pb}$, and $\mathrm{Zn}$ in sediment cores of the Cananéia-Iguape coastal system, Southeastern Brazil. Marine Pollution Bulletin, 127, 1-9.

TUNDISI, J. G. \& MATSUMURA-TUNDISI, T. 2001. The Lagoon Region and Estuary Ecosystem of Cananéia, Brazil. In: SEELIGER, U. \& KJERFVE, B. (eds.). Coastal Marine Ecosystems of Latin America, Ecological Studies. Berlin, Germany: Springer Berlin Heidelberg.

TUREKIAN, K. K. \& WEDEPOHL, K. H. 1961. Distribution of the elements in some major units of the Earth's Crust Geological Society of America Bulletin, 72, 175-192.

USEPA (U.S Environmental Protection Agency). 1994. Method 200.8, Revision 5.4: determination of trace elements in waters and wastes by inductively coupled plasma - mass spectrometry, vol. 4. Washington USA: USEPA.

USEPA (U.S Environmental Protection Agency). 1996. Method 3050B: acid digestion of sediments, sludges, and soils. Washington USA: USEPA.

USEPA (U.S Environmental Protection Agency). 2004. Contamination sediments science priorities: United States Environmental Protection Agency Science Policy Council. Washington USA: USEPA.

USEPA (U.S Environmental Protection Agency). 2007a. Method 3051A: microwave assisted acid digestion of sediments, sludges, soils, and oils. Washington USA: USEPA.

USEPA (U.S Environmental Protection Agency). 2007b. Method 7010: graphite furnace atomic absorption spectrophotometry. Washington USA: USEPA.

VIARENGO, A., PONZANO, E., DONDERO, F. \& FABBRI, R. 1997. A simple spectrophotometric method for metallothionein evaluation in marine organisms: an application to Mediterranean and Antarctic molluscs. Marine Environmental Research, 44, 69-84.

WARD, D. J., PEREZ-LANDA, V., SPADARO, D. A., SIMPSON, S. L. \& JOLLEY, D. F. 2011. An assessment of three harpacticoid copepod species for use in ecotoxicological testing. Archives of Environmental Contamination and Toxicology, 61(2), 414425.

WIENER, J. G. \& SPRY, D. J. 1996. Toxicological significance of mercury in freshwater fish. In: BEYER, W. N., HEINZ, G. H. \& REDMON-NORWOOD, A. W. (eds.). Environmental contaminants in wildlife: interpreting tissue concentrations. Boca Raton, USA: Lewis Publishers. 
WRIGHT, D. A., MIHURSKY, J. A. \& PHELPS, H. L. 1985. Trace metals in Chesapeake Bay oysters: intra-sample variability and its implications for biomonitoring. Marine Environmental Research, 16, 181-197.
ZHANG, J., ZHANG, W., LI, J., SHI, Z. \& PU, S. 2004. Relation between precipitation and sediment transport in the Dasha River Watershed. Chinese Geographical Science, 14(2), 129134. 